\title{
Soil Microorganisms and Their Potential in Pesticide Biodegradation: A Review
}

\author{
M. U. Mustapha*1,2, N. Halimoon ${ }^{2}$, W. Lutfi W. Johari ${ }^{2}$ and M.Y. Abdul Shukor ${ }^{3}$ \\ ${ }^{1}$ Desert Research Monitoring and Control Centre, Yobe State University, 1144 \\ Damaturu, Nigeria, ${ }^{2}$ Department of Environmental Sciences, Faculty of Environmental \\ Studies, Universiti Putra Malaysia, 43400 UPM Serdang and ${ }^{3}$ Department of \\ Biochemistry, Faculty of Biotechnology and Biomolecular Sciences, Universiti Putra \\ Malaysia, UPM, 43400 Serdang, Selangor, Malaysia
}

\begin{abstract}
$\mathbf{P}$ ESTICIDES play an important role in preventing insect pests and weeds in crops. However, excessive use of pesticides has been known to be unsafe, due to their toxicity to non-target organisms and the ecosystem. Biodegradation is an innovative approach for decontaminating pesticide pollution. However, compared with the list of extensively used pesticides there are few well-characterized strains of microbes that transform pesticides into less-toxic or more labile products at environmentally useful rates. Fortunately, the technology required to isolate and characterize such microbial strains has improved immensely in the recent years. Furthermore, recent experimental developments have made practical the modification of potentially beneficial biodegradation genes so that they may be optimally expressed in a wide range of microbial species. This reviews article explore the recent studies that have focused on biodegradation of pesticide residues, the mechanism of microbial degradation of pesticides, the factors that affect the degradation of pesticides and the new application of microbial degradation of pesticides.
\end{abstract}

Key words: Biodegradation, Pesticides, Fungi, Bacteria, Immobilization, Molecular.

\section{Introduction}

Pesticides are chemical substances used to control, prevent or destroy pests including insects, nematodes, microorganisms and weeds (Anderson et al., 2011 and Porto et al. 2011). The world human population continues to grow at about two percent each year which resulted in high demand for resources. The consumption of pesticides has advanced modern societies by increasing the amount of agricultural yield and production which reduce the cost of agricultural related materials. Obviously, the use of pesticide has turn out to be an essential part of modern society due to constant evils of pests, therefore pesticide usage is difficult to be stopped. Pollution of water, air and soil by pesticides has become a worldwide problem (Sultan \& Kertesz, 2015 and Sukul \& Spiteller, 2001). True accurate data about the effects of pesticides is still scanty (Chanika et al., 2011). Several developed nations have already banned or restricted the use of most these toxic compounds but yet they are still manufactured and are available in the markets (Almeida-Gonzalez et al., 2012). The consumption of pesticides in current farming system has become inevitable. While many local farmers are still not fully aware of the hazards that may arise as a result of using such toxic chemicals (Boada et al., 2016). Several information are available on the existence of insecticide residues in soil and water bodies and the atmosphere (Banerjee \& Mukherjee, 2017 and Singh \& Singh, 2017). Studies are also available on the level of pesticide residues present in agricultural products (Barriada-Pereira et al., 2005). Pesticide residue affects the atmosphere through its volatilization as a result of wind action. Pesticides residues further transport from the site used to other places or leach through the soil by means of percolation to contaminate ground water (Aamand and Smets, 2014). Pesticides used in agricultural fields directly or indirectly are in contact with non-target organisms. The persistence of pesticide in the environment is of major concern due to their imminent toxicity, carcinogenicity and possibility to bio accumulate in food chain and food web (Almeida-Gonzalez et al., 2012). Detailed chemical composition and characteristics pesticides are presented in Table 1 
TABLE 1. General Characteristics of some classes of Pesticides (Adapted from Badii and Landeros, 2007; Biju and Krishnamurthy, 2017)

Pesticides

Organochlorines

Carbamate

Pyrethroid
Soluble in lipids, they accumulate in Carbon atoms, chlorine, hydrogen fatty tissue of animals, are transferred and occasionally oxygen. They are through the food chain; toxic to a variety nonpolar and lipophilic of animals, long-term persistent

Soluble in organic solvents but also in water. They infiltrate reaching groundwater, less persistent that chlorinated hydrocarbons; some affect the central nervous system. They are absorbed by plants and then transferred to leaves and stems, which are the supply of leaf-eating insects or feed on wise

Carbamate acid derivatives; kill a limited spectrum of insects, but are highly toxic to vertebrates. Relatively low persistence

Possess central phosphorus atom in the molecule. In relation whit organochlorines, these compounds are more stable and less toxic in the environment. The organophosphate pesticides can be aliphatic, cyclic and heterocyclic.

Chemical structure based on a plant alkaloid Physostigmavenenosum

Affect the nervous system; are less persistent than other pesticides; are the safest in terms of their use, some are used as household insecticides.

Compounds similar to the
synthetic pyrethrins (alkaloids
obtained from petals of
Chysanthemuncinerariefolium).

Only the Bacillus thuringiensis (Bt) and its subspecies are used with some frequency; are applied against forest pests Viruses, microorganisms or their and crops, particularly against butterflies. metabolic products Also affect other caterpillars.

\section{Classifications of pesticides}

The World Health Organization anticipated to categorize the pesticides based on their toxicity ranking order from lowest to highest toxicity in numbers I through IV, being extremely toxic, highly toxic, moderately toxic and slightly toxic, respectively (WHO, 2010). Approximately five hundred different pesticide formulations are certified worldwide to handle various kind of pests in agriculture (Arias-Estévez et al., 2008). The most synthetic pesticides consumed were categories into this four group's organophosphate, organochlorines, carbamates, and pyrethroids.

Fate and transportation of pesticides in the environment

Introduction of pesticide to the environment is J. Sus. Agric. Sci. 44, No. 2 (2018) mainly influenced by many processes and these processes explain their fate, persistence as well as their movement in the environment. It is very essential to know the fate as well as behavior of pesticides as it can aid in warranting effective and ecologically harmless application of pesticide in the environment (Menzie, 1972). Run-off from aquatic habitats may transport pesticide away from intended sites to non-target specie (Wong, 2006). Several factors influencing the fate of pesticides include, their adsorption, absorption, Run-off, microbial degradation, volatilization, photochemical decomposition uptake by plant and chemical degradation. Pesticides application to soil may disappear to the atmosphere, taken up by plants or consumed by living organisms 
in the soil; descend underground, degradation by solar energy, i.e. photochemical degradation or breakdown through microbial action. The difference in pesticides chemical structures plays an important role in defining the movement of pesticides in the environment. Some pesticides are water soluble and can move with water. Some volatize easily meaning they can transform from liquid to gas making them move easily in the atmosphere. Some pesticides may be transformed to nontoxic to both their target species and the environment while others may degrade into more toxic than their parent compound. Pesticides classification is summarized in Table 2

TABLE 2. Pesticides classification according to their target species, chemical state and mode of action proposed by(adapted from Arias-Estevez and Fernandez-Calvino, 2013)

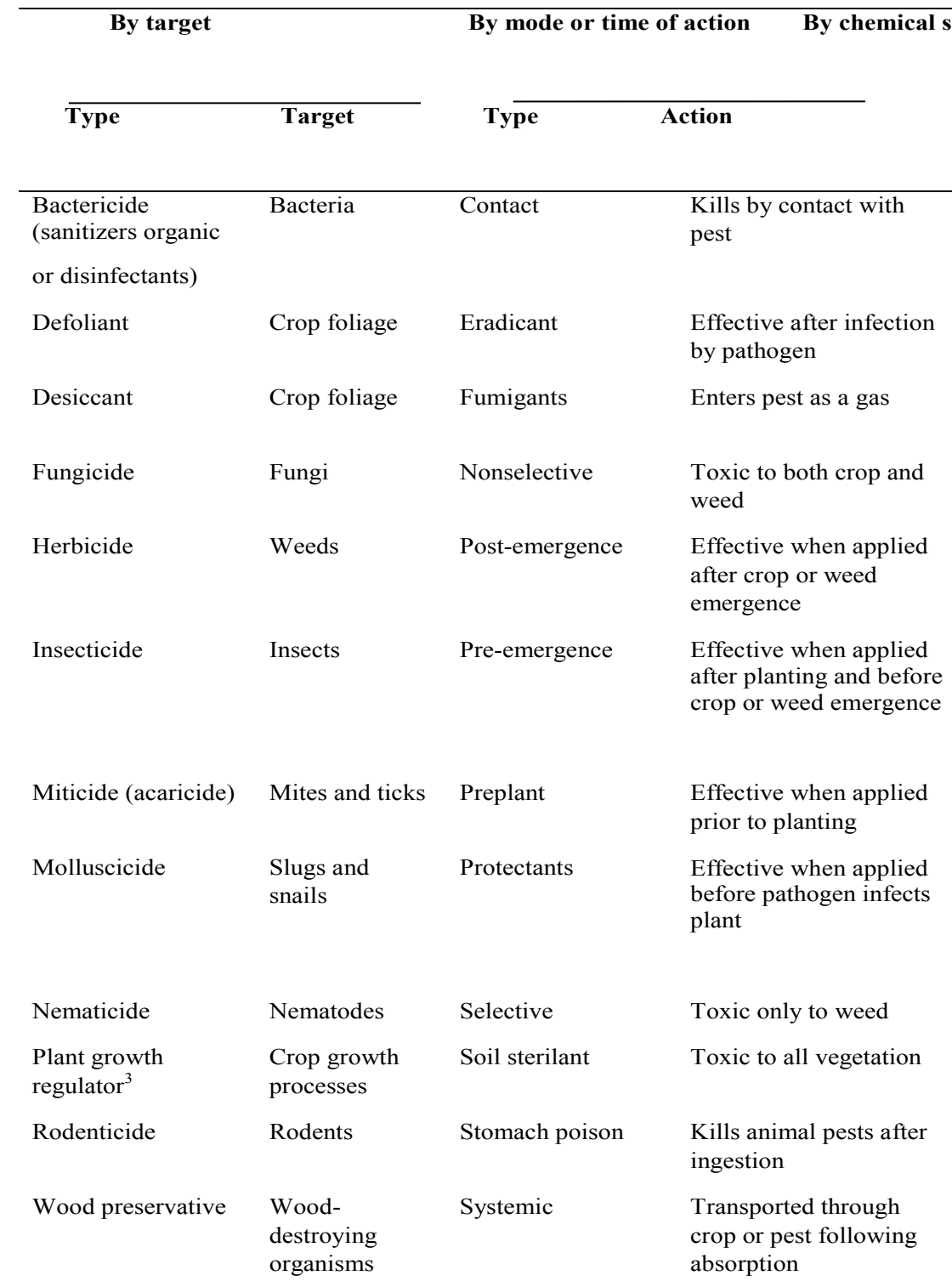

Pesticides can be either organic or inorganic. Most of today's chemicals are organic.
Commonly used inorganic pesticides include copperbased fungicides, lime-sulfur used to control fungi and mites, boric acid used for cockroach control, and ammonium sulfamate herbicides

\author{
Organic insecticides can \\ either be natural (usually \\ extracted from plants or \\ bacteria) or synthetic. Most \\ pesticides used today are \\ synthetic organic chemicals. \\ They can be grouped into \\ chemical families based on \\ their structure
}




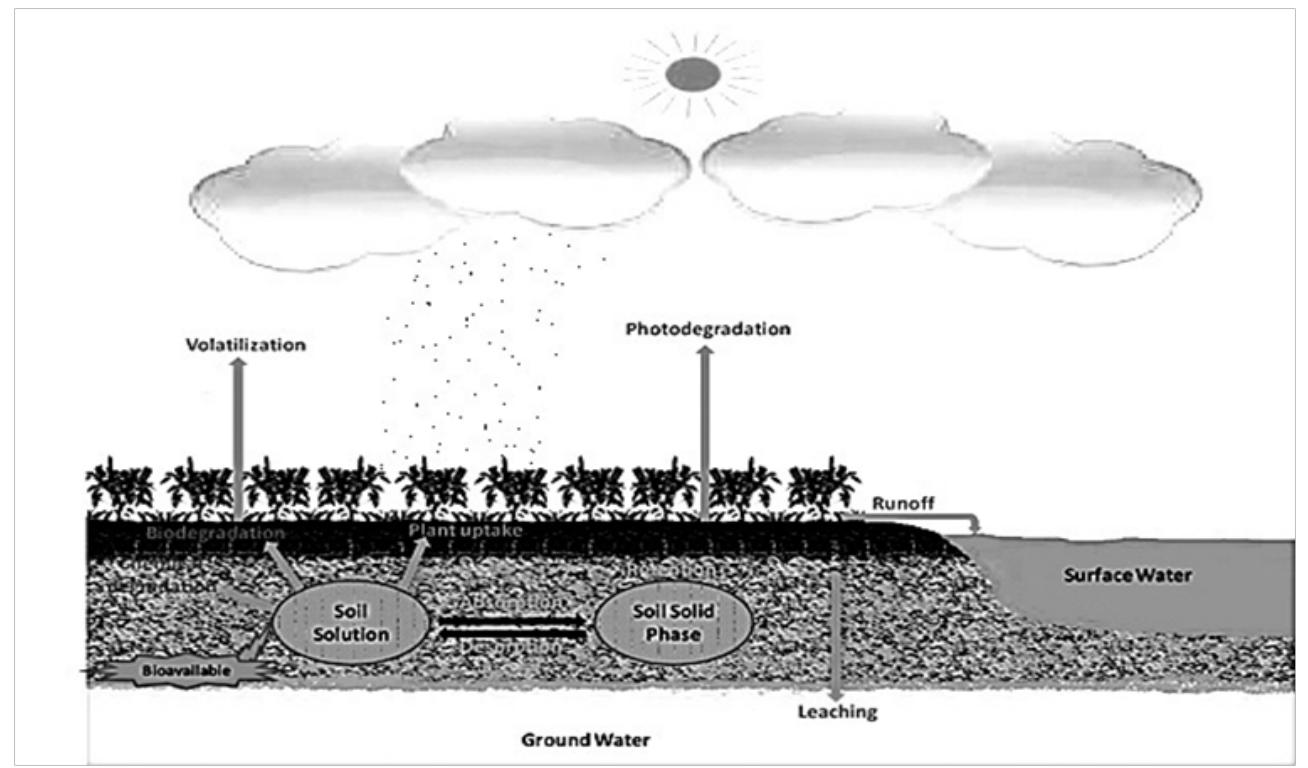

Fig.1. Fate and Transportation of Pesticides in the Environment (D. K. Singh, 2008)

\section{Absorption}

These deals with the ability of plants, animals, humans or microorganisms absorb or take-up chemicals (Cobb and Anderson, 2009). Pesticides absorption by a target and non-target organisms is usually affected by environmental circumstances as well as the physical and chemical properties of the pesticide and the soil.

\section{Adsorption}

This is reversible process of bonding of gas, liquid molecules or dissolved solids to a particular surface. Adsorption of pesticide in soil occurs through soil components (organic matter and clay particles). It has been established that a large portion of pesticide used in agricultural field is retained by soil segment as a result of adsorption (Blume and Ahlsdorf, 1993). This usual phenomenon thus affects the rest of the processes such as volatilization leaching and uptake by plants. Many factors may effect pesticides adsorption and desorption in soil such as soil texture, soil moisture and soil acidity. The adsorbed portion may differ from little quantity up to $90 \%$ of the pesticide used depending on the physicochemical properties of the soil as well as the pesticide (Ye, 2003). Usually, clay soils which contain higher content of organic matter are highly adsorptive than sandy soils, due to presence of supplementary particle surface area on which the insecticides are bind. Pesticide adsorbed by soil are unlikely to leach, volatilize, or undergo microbial degradation. Once a pesticides are bind by soil components, they would not be accessible for absorption by plants or animals (Forano and Besse-Hoggan, 2011).

\section{Volatilization}

Volatilization is the conversion of pesticides into gas from solid or liquid and plant surfaces. It is the movement of pesticide vapors through the air. Farm workers and bystanders may be at risk of pesticide exposure through inhalation of these vapors. Volatilization is considered differently than pesticide movement either by spray drift, erosion, or windblown particles. Volatilization of pesticide is influence by environmental conditions such as physicochemical properties of soil such as soil moisture, organic matter and soil texture.

\section{Run-off}

It is the horizontal movement of water over a sloping surface. These transports of insecticides may amalgamate in aqueous solution or bind to eroding soil. Depending on the climatic situations of soil such as rainfall, the pesticide and their derivatives in soil are transported to the other areas by runoff (Chikere and Okpokwasili, 2016). Environmental factors like soil texture, soil moisture and amount of rainfall and irrigation determine the level of pesticide runoff. The runoff of pesticides generally occurs when the pesticide application is followed by continuous rainfall. Also physical and chemical parameters of the pesticide such as adsorption to soil influence runoff or absorption by plant. Figure 1 explained the fate and transport of pesticides in the environment. 


\section{Leaching through soil profile}

Leaching is the vertical movement through the soil which aid the transports of pesticides to groundwater under certain circumstance. Contrary to runoff, which is the movement of water on the soil surface, leaching is the movement downward through the soil profile(Sethunathan and Johri, 2002). Insecticide in the soil solution might leached downwardto the underground level over an extended period of time which result in delayed pollution of aquifers. The shallower the depth to ground water, the less soil there is to perform as a filter. When pesticides are exposed to soil layers with higher depths, more chance exists for the chemicals to dilute, degrade or sorb before going downward(Nejidat and Ronen, 2011). Neighboring surface water is more liable to contamination when pesticides are applied to highly erodible soils or to over-irrigated or rainsoaked fields. Studies examining the leaching of pesticide were conducted both in field and laboratory scale using packed soil column and the result from the studies revealed that pesticides leach out through the root zone and the leaching process is control by may processes like physical chemical and biological parameters of the pesticide and soil and volume of rainfall events after the use of the pesticide(Nousiainen et al., 2015 and Mingorance \& Pena, 2014) (Figure 1).

\section{Effect of pesticide on soil microbes and plants}

The extensive use of pesticides causes their buildup in soils and directly or indirectly affects the functional activities of non-target soil microbiota. Microorganisms and plants species are among the most essential biological agents that help in the degradation toxic constituents or allow their recycling in the environment. Soil micro flora, essentially fungi, protozoa and bacteria significantly contribute in making the soil fertile through their primary catabolic role in the degradation of plants and animal residues in the cycling of the organic, inorganic nutrients content of soil (Moorman and Koskinen, 2007). Pesticide that disrupt the activities of the soil microorganisms could be expected to affect the nutritional quality of soils and would therefore, have serious ecological consequences. Pesticide applied to soils transformed by biological and nonbiological processes into different transformation products. These transformations happen through different mechanisms physical, chemical and biological agents in which microbes play an important role. The transformation mechanism includes oxidation hydrolysis reduction conjugation which are catalyzed by various types of enzymes resulting in less bio active products (Brogan and Relyea, 2017).

\section{Effect of pesticides on humans}

The extensive use of pesticides has led to serious health effects to humans and the ecosystem. Most acute pesticides poisonings to humans are caused by organophosphate. Pesticides sprayers, loaders and agricultural farm workers are at high risk of pesticides exposure. Many previous literatures shows that pollution as a result of pesticides application may be linked to several illnesses such as neurological problems, immune system disorders, human cancers, mental as well as reproductive effects in mammals. Children may be at high risk as a result of pesticides exposure through breast milk and food (WohlfahrtVeje et al., 2011). Consumption of pesticide polluted crops causes life-threatening illnesses in humans and animals.

\section{Effect of pesticides on aquatic environment}

Exposure to pesticides result in possible severe health problems. Approximately 1 million deaths and prolonged sicknesses are reported each year as a result of pesticide poisoning globally. Mortality and loss of zooplankton due to pesticide exposure is an example of direct consequence of pesticides on marine and sea animals. Surface movement of pesticides into waterways and rivers is extremely dangerous to aquatic life, sometimes it may kill all the fish in a particular river. The pesticides used are mostly organic molecules with hydrophobic components triggering prompt sorption of the pesticides residue to the soil constituent and then washed into the aquatic environments in dissolved forms (de Moreno and Moreno, 2004) Universidad Nacional de Mar del Plata, Funes 3350, Mar del Plata 7600, Argentina. kmilglior@ mdp.edu.ar $<$ /auth-address $><$ titles $><$ title $>$ Orga nochlorine pesticides sequestered in the aquatic macrophyte Schoenoplectus californicus (C.A. Meyer. Sorbed pesticide residues have a tendency to be less degradable compared with dissolved ones subsequently they are less available to the degrading action of microbes, ultraviolet light and photochemical degradation (Qu and Yang, 2009). Hence widespread consumption of pesticides would lead to accumulation of these compounds in sediments of stream and river.

\section{Persistence of pesticides in the environment}

The perseverance of pesticides is generally determine using half-life, which is, the time taking for half of the original concentration used to breakdown (Fantke and Trapp, 2015). Generally, the longer the half-life, the more the likely is for pesticide transport, a pesticide will breakdown to $50 \%$ of the original volume after a single half-life and $25 \%$ will remain after two half-lives and nearly $12 \%$ will remain after three half-lives. This continues until the volume left over is nearly zero (Jacobsen et al., 2015). Pesticide persistence is among the most essential aspects in determining the fate of pesticide as well as their effects 
in the environment. The persistence of pesticides may be classify as persistent, non-persistence, moderately persistent, and permanently persistent (Walker and Wright, 2002). Organohlorines pesticides used in agriculture such as Aldrin, Dieldrin and DDT are highly persistent (Mansouri et al., 2017).

\section{Methods of pesticide remediation}

Considerable amounts of pesticides are applied to agricultural field globally. Some pesticides degrade quickly within few days whereas, others are complex and may take several years to degrade due to their persistence. Complete fate and pathways of several insecticides degradation in the environment are not fully understood. Several insecticides do not reach their targets rather contaminate plants, animals and soils. Remediation of polluted areas usually takes a very long time depending on nature of pollutant. The soil remediation technology is currently evolving as novel scientific area for multi-disciplinary researches. The remediation approaches for the management of pesticide polluted areas includes;

\section{Low temperature thermal desorption}

This is an ex situ remediation approach, often applied to remediate areas polluted with pesticides. Low temperature thermal desorption usually treat volatile and semi-volatile compounds, such as pesticides the method remediate pesticides from sediments and sludge. The pollutant is usually heated at about 300 to $1000^{\circ} \mathrm{F}$, which causes volatilization, instead of removal of the compounds. While subsequent organics pollutants in the polluted gas stream are depolluted by moving in the condenser or seized by carbon adsorption beds. The condenser transforms the gas into aqueous form for advance treatment whereas the carbon adsorption beds immobilize, but never rescind the pollutants. The method needs advance services and are relatively not cost effective. The method do not treats inorganic compounds or limited to few concentrations.

\section{Incineration techniques}

This is another technology that has commonly used to treats pesticide polluted areas. The incineration approach is greatly applicable for the treatment of soil, sediments and sludge contaminated with organic chemicals. In this method oxygen and heat are applied to the polluted areas while the organic substances are consecutively oxidized. Initial phase of incineration, polluted media pass through a very high temperature usually from 1,000 to $1,700{ }^{\circ} \mathrm{F}$ which also cause oxidation as well as volatilization of the pollutants. The second phase of incineration technology runs by heating from 1,800 to $2,000^{\circ} \mathrm{F}$ which would completely eliminate the pollutants. Incineration technology remove almost all the contaminants however, constraint like high operation costs. Small amounts of polluted media can be treated off-site by centralized facilities however; transporting polluted and hazardous material increases the liability.

TABLE 3. Factors affecting Pesticides Persistence in the environment

\begin{tabular}{|c|c|}
\hline Environmental Factors & Role in Chemical Degradation \\
\hline Sunlight & $\begin{array}{l}\text { Radiation from the sun breaks certain chemical bonds, creating break down } \\
\text { products. }\end{array}$ \\
\hline Microbes & Bacteria and fungi can break down chemicals, creating biodegradation products. \\
\hline Animals/Plants Metabolism & $\begin{array}{l}\text { Plants and animals can change chemicals into forms that dissolve better in water } \\
\text { (metabolites). This makes removal from the body easier. }\end{array}$ \\
\hline Water & $\begin{array}{l}\text { Water breaks chemicals apart to make pieces that dissolve better in water } \\
\text { (hydrolysis). This is typically a very slow process. }\end{array}$ \\
\hline Dissociation & Chemicals can break apart into smaller pieces (dissociation products). \\
\hline Sorption & $\begin{array}{l}\text { Chemicals that stick tightly to particles can become inaccessible and/or move } \\
\text { away with those particles. }\end{array}$ \\
\hline Bioaccumulation & $\begin{array}{l}\text { Some chemicals can be absorbed by plants/animals from the soil, water, food, and } \\
\text { air. When the plant/animal is exposed again before it can remove the chemical(s), } \\
\text { accumulation can occur. }\end{array}$ \\
\hline
\end{tabular}




\section{Bioremediation techniques}

These is an innovative technology that is often being chosen for the cleanup of areas polluted with pesticides and other toxic chemicals (Azubuike et al., 2016). Due to cost-effectiveness and environmental friendly nature, bioremediation is becoming more eye-catching cleanup technology. Bioremediation process influences the rate of the natural pollutants degradation by microorganisms by providing nutrients and energy sources (Azubuike et al., 2016). Bioremediation methods lead to complete mineralization of pollutants into water and carbon dioxide without evolving any intermediates. Bioremediation processes can be generally classified into two groups: ex-situ and in-situ. Ex-situ bioremediation technologies include bioreactors, bio filters, land farming and some composting methods. In-situ bioremediation technologies include bioventing, liquid delivery systems, biosparging, biostimulation, and some composting methods. In-situ bioremediation tend to be more attractive, as less equipment is required in the process, generally have a lower cost and generate fewer disturbances to the environment. However, the difficulties linked with implementing in-situ bioremediation have limited their application in the field conditions (Vogt and Richnow, 2014). The technologies of bioremediation based on the principles of bio-augmentation and bio-stimulation comprise of land farming, bioreactor, bioventing and composting.

\section{Phytoremediation techniques}

Phytoremediation is an environmental friendly tools for remediation of contaminants using plant species. The fact that herbicides are intended to destroy plants, the application of phytoremediation technology to remove them might be very complex (Zhao and Coats, 2006). Several researches were conducted to determine the efficiency of removing persistent environmental contaminants using many plant species and more findings were already being reported. Plants have the capability of take-up and storage of high toxic compound concentrations in their roots, shoots and leaves, known as phyto-extraction. The plants are then harvested and disposed of in an appropriate way, for instance in waste landfill. This method results in at least $90 \%$ reduction in waste volume over the equivalent concentration of contaminated soil (Henderson et al., 2006). The plants involves in this form of remediation are called the hyperaccumulators. The plants specie mostly used in phytoremediation remediation include; cabbage, mustard plant, alpine pennycress and broccoli etc. Phyto-transformation is a situation in which the pollutants are transform by the plants into less toxic, less mobile or more stable form. These includes the following; phyto-degradation, which is the metabolism of the organic pollutant by the plant enzymes and phyto-volatilization, the volatilization of pollutants as they pass through the plant leaves (Alkorta and Becerril, 2002). Phyto-stabilization immobilizes the pollutants and decreases their movement over the soil by absorbing and binding leachable elements to the plant structure. This process efficiently decreases the bioavailability of the harmful pollutants. Almost all vegetation present at contaminated areas will contribute to phyto-stabilization (Ramírez-Sandoval and Domínguez-Ojeda, 2012). While between the soil and root boundaries, known as the rhizosphere, there is bulky and very active communities of microorganisms. The rhizosphere environment is rich in microorganisms with high metabolic activity, which enhance the biodegradation rate of pollutant (Singh and Singh, 2017). Generally, the plant species are not directly involved in the biodegradation process, but serves as a catalyst for increasing microbial growth and activity, which then increases the biodegradation potential. However, the rhizosphere has limitation in its remediation ability because it does not extend far from the root. This process is often called the phyto-stimulation or plant-aided bioremediation (Henderson et al., 2006) (Figure 2).

\section{Biodegradation of pesticides}

Biodegradation is an effective and environmentally friendly method that involve the use of natural materials to neutralize environmental pollutant (Porto et al., 2011). Microbes like bacteria, algae and fungi play an important role in pesticide dissipation in soil and other environmental samples. The interaction between pesticides and microbes has received great deal of attention over the years. Previous approaches of pesticide decontamination includes the use of incineration and landfills which produce secondary pollution complications because of leaching of pesticides into the nearby soil and underground water table as well as possible releases toxic by-product (Ashiq and Tahir, 2016). Many researchers have reported pesticides biodegradation using different microbial populations in different environmental matrix (Akbar \& Sultan, 2016, Natália Alvarenga et al., 2018, Mobasherizadeh \& Naser, 2017and Zhao et al., 2015). The effectiveness of pollutants degradation differs significantly among diverse microbial communities and even among species belonging to the same populations. The degradation of pesticides by microbes may be characterized base on two major categories as metabolic degradation and co-metabolic degradation. 


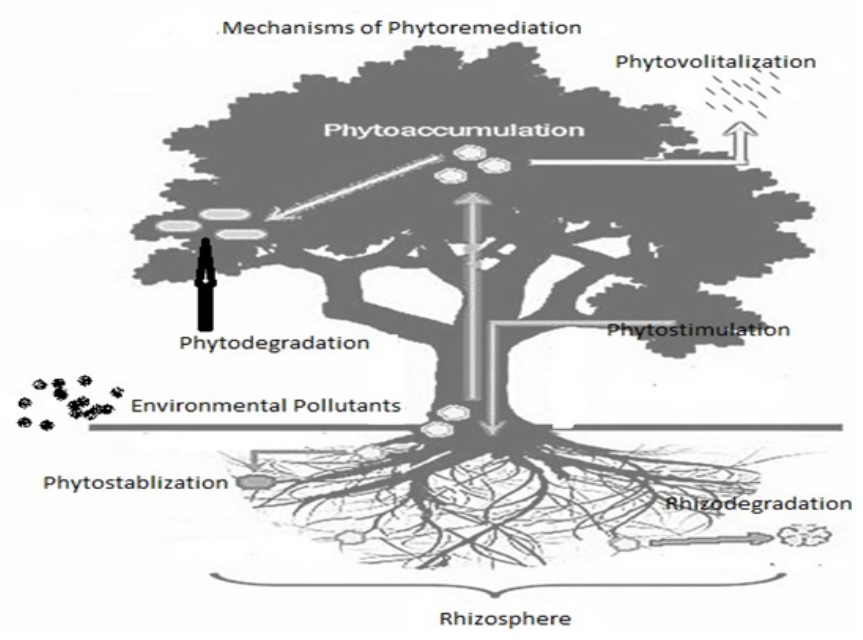

Fig. 2. Mechanism Involves in Pesticide Phytoremediation adapted from (Velázquez-Fernández et al., 2012)

\section{The metabolic pesticide degradation}

This comprises the biodegradation of pesticides which perform by the microorganisms present in soil authorizing particular catabolic enzymes to perform full mineralization of pesticides. However, the metabolic degradation may sometimes result to incomplete degradation causing the emergence of other byproducts (Badawi et $a l ., 2009)$ The enzymes needed for pesticides metabolic degradation are either produced by a distinct microbial specie or by several microorganisms operated as microbial consortium (Fournier et al., 2004).

The co-metabolic pesticide degradation

These relates to the broad-spectrum degradation of pesticides by microbes. Normally, the method is not harbored by any phenomenon it is taking place due to existence of enzymes that can degrade toxic substances. In this situation, the target compound does not support the growth of the microorganisms. Therefore, the proportion of pesticide dissipation is associated to the extent of the microbial biomass and never increase even after frequent introduction to pesticide treatment (Akoijam and Singh, 2014). There are many evidence and laboratory data showing the environmental significance of co-metabolism. It has been mentioned that co-metabolism may be responsible for the degradation of many organic compounds like pesticides which do not tolerate the growth of microbes. Chemicals such as DDT, di-phenyl aliphatic, and polychloroaromatics have been defined as recalcitrant compounds as a result of recurrent failures to isolate microorganisms with ability of using them as sole sources of carbon and energy for growth. Nevertheless, co- metabolism of these elements has been revealed to occur in laboratory settings and may possibly be a significant process for remediation of these pesticides in the environment. For instance, chlorobenzilate, a diphenyl aliphatic having similar structure with Dichlorodiphenyltrichloroethane, was exposed to oxidation by unicellular pigmented yeasts called Rhodotorula gracilis in a culture media supplemented with yeast extract and mannitol salt agar.

\section{Principles of pesticide biodegradation}

The complete pesticide biodegradation comprises of parent compound oxidation to produce $\mathrm{CO}_{2}$ and $\mathrm{H}_{2} \mathrm{O}$ which as a result offers carbon and energy for the microbial growth as well as reproduction. Every stage in degradation process is usually catalyzed by a particular enzyme formed by enzymes located in the microbial cell (Jacquet et al., 2016). The degradation of organic compounds by both external and internal enzyme may cease at some stage if a suitable enzyme does not exist. The nonexistence of suitable enzyme is mostly the reasons for pesticides persistence in the environment (Van Dyk and Pletschke, 2011). In some instance if the suitable degradative microbes are absent, or if the capability of the degradative microbes has been reduced as a result of the pesticide toxicity then specific microbial community may be introduced so as to increase the metabolic action of the already present microbes. The microbes might be natural microorganism or genetically modified microbes (Shah and Chellapandi, 2015). The microbial populations in soil environments are diverse populations rather than a single microbial strain. Microorganisms may develop the mechanisms to interact with organic 
and inorganic constituents either chemically or physically, leading to complete degradation of the target molecule (Sethunathan and Naidu, 2011).

Bacteria involvement in biodegradation of pesticides

Microbial populations in soil are one of the most complex and diverse groups on earth. The diversity of microorganisms symbolizes their metabolic, genetic and morphological features. Studies on molecular basis using small-subunit rRNA and rDNA sequencing systems displayed an unbelievable diversity and distribution among microbes in the environment ( $\mathrm{Hu}$ and $\mathrm{Li}, 2013)$. Microorganisms are virtually adapted to all environments present on the earth. Studies have recurrently established that minor changes in the environmental conditions significantly affect the community of the microbial species. The fate of pesticides in the environment is mostly influenced by the activity of microbes. Several classes of pesticides are readily degraded by microbes, while, some were confirmed to be recalcitrant. Biodegradation by microbes depends not only on the availability of degradative microbes with suitable degradative enzymes, but also on a varied degree of ecological factors. Different groups of bacteria species such as Pseudomonas, Alcaligenes, Rhodococcus Bacillus and Flavobacterium, metabolize pesticides as shown in Table 4. Microbes carry-out a different kind of metabolisms, using everything from solar energy to organic carbon as well as inorganic substance as energy sources, which also have the ability to change between these metabolic modes (Fang et al., 2014). Some microbes may exist in several ranged of physicochemical settings, from boiling thermal springs to acid mine drainage. Several microbes have developed catabolic degradative mechanisms to different organic compounds i.e. majority of degradative microbes can utilize external compounds as an energy and nutrient source (Alvarenga et al., 2018, Azadi et al., 2017, Liu et al., 2016 and Wang \& Xie, 2014).

Fungi involvement in biodegradation of pesticides Myco-remediation or application of fungal specie as bioremediation agents dated back to some few decades ago (Seleghim and Porto, 2014). Researchers have tested many fungal species for their ability to degrade different organic compounds. For instance the discovery of white-rot specie of fungi as bioremediation agent has inspired and open way to many researchers.
Recently, bioremediation technologies using fungus has attract significant attention. Fungus are widespread in the environment while the literature on the ecology of fungal species is enormous. In spite of this, the reports on potential of fungi as bioremediation agent are scares (Mariana et al., 2010). Furthermore, the biology and ecology of mycoremediation have not often been studied (Aust \& Benson, 1993 and Mori et al., 2017). Fungal species have strong enzymatic action that makes them grow well on many natural and synthetic constituents. Fungal specie release greater amounts of many extracellular enzymes into their exterior surroundings and can remediate several compounds to small fragments (Jda et al., 2013). Though fungi are static they can react more rapidly to varying environmental circumstances for their survival. They produce unique extracellular enzyme. Furthermore, they are well suited for bioremediation due to specificity of their catabolic enzymes and ability to form mycelial networks as well as independence of using compounds as a growth substrate (Friloux \& Walker, 2002 and Kiyota \& Sato, 2010). Fungal species can escape negative circumstances in heterogeneous environments which offer them an advantage. Majorities of fungi are multicellular eukaryotic specie and have noble extracellular enzyme, and peroxidase removing many groups of organic compounds. Several organic chemicals including PAHs, pesticides and PCBs were effectively degraded by common fungal species. An aerobic fungal specie Chrysosporium strain was found to be effective for remediation of soil contaminated with organochlorines pesticides the specie was revealed to have degraded the organochlorine using several pathways. Fusarium verticillioides strain was isolated from the leaves of tequila agave plants using enrichment methods was able to degrade lindane under aerobic conditions by using it as carbon and energy source (Feijoo and Lema, 2008). The white rot fungus Phanerochaete chrysosporium is one of the best agent of bioremediation, as it is more effective than other species of fungus in the degradation of poisonous or insoluble compounds (Mori et al., 2017). Several other white-rot fungal species were tested for the degradation of persistent organic substances, e.g., Pleurotus tuberregium, Pleurotus ostreatus, Bjerkandera adusta, Trametes versicolor, Agaricus bisporus, Pleurotus pulmonarius and Lentinula edodes (Khardenavis \& Purohit, 2016 and Shimizu $\&$ Kamei, 2017) (Table 5). 
TABLE 4. Bacterial Species Used For Pesticides Biodegradation

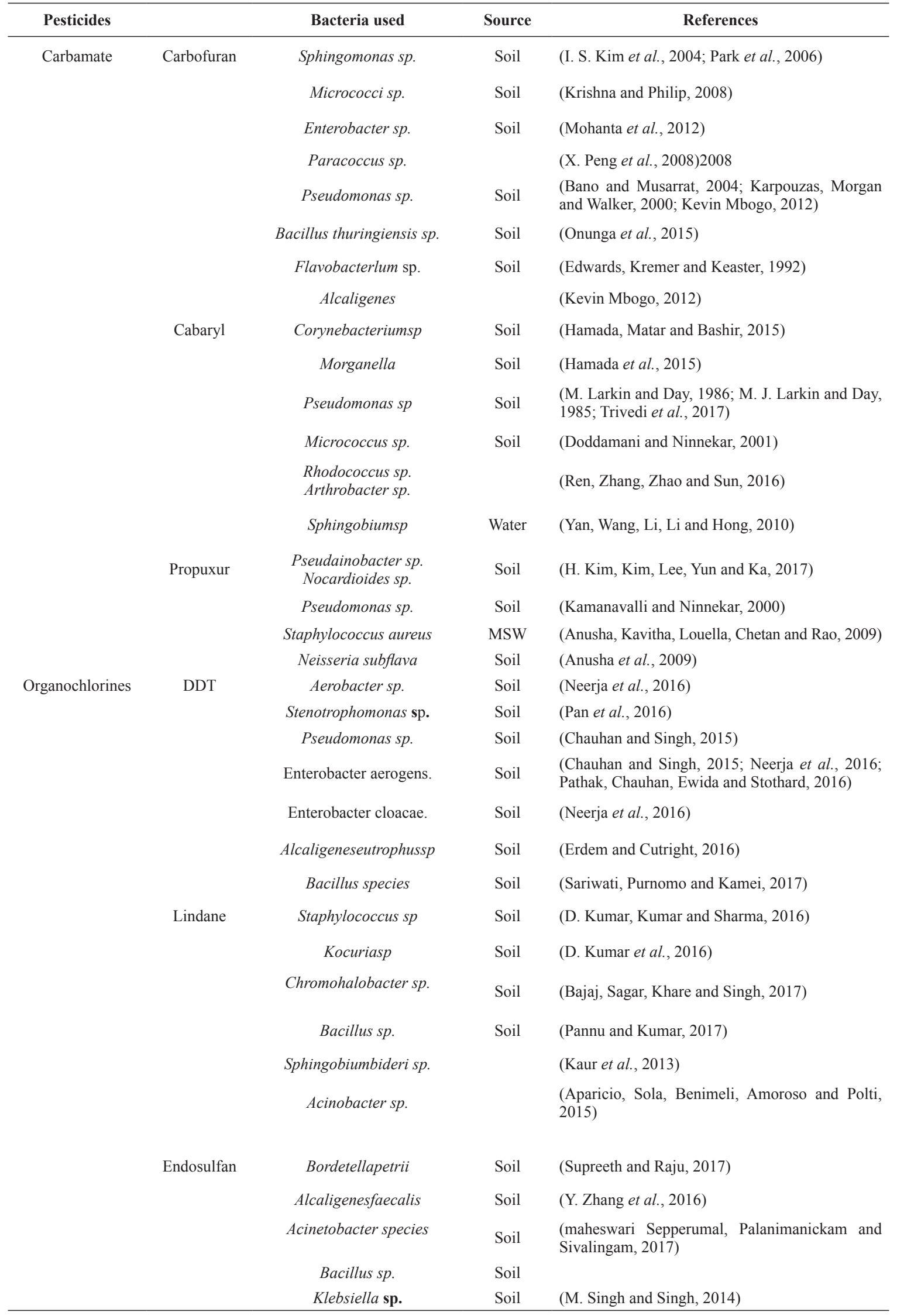


TABLE 4. Cont.

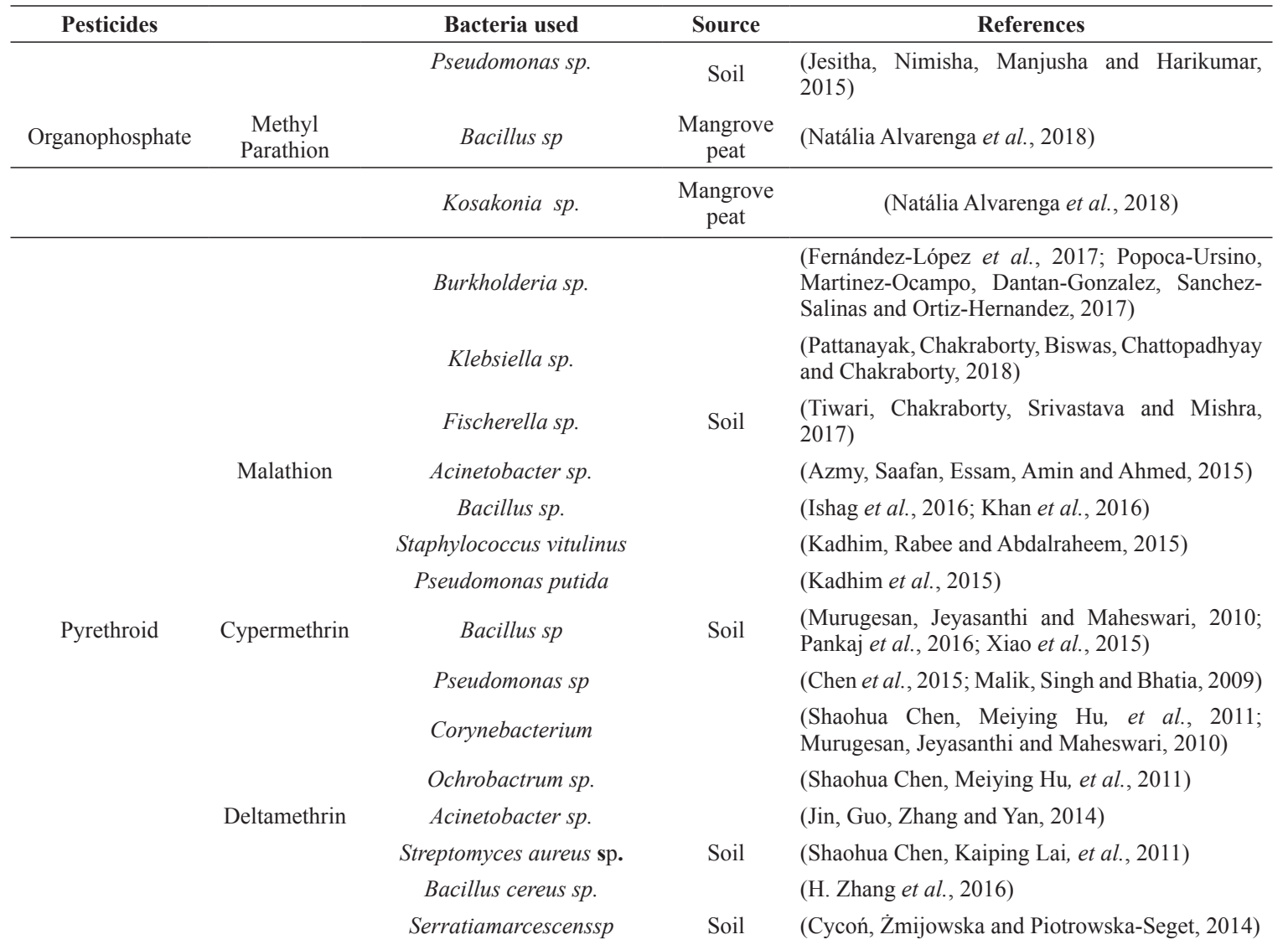

Degradative pathways of some pesticides by microbes

Degradation of pesticides occurs through various mechanisms. Generally, the degradation of pesticides results in the production of carbon dioxide $\left(\mathrm{CO}_{2}\right)$ and water $\left(\mathrm{H}_{2} \mathrm{O}\right)$ by the oxidation of parent compounds. Many studies were conducted and showed that degradation happens under both aerobic and anaerobic conditions, under the influence of gram positive and negative bacteria as well as some fungi. Biological physical and chemical agents play a vital part in the transformation process of different pesticides into several metabolites. The mechanisms of pesticides transformation comprise of hydrolysis, oxidation reduction, conjugation hydration mineralization and isomerization. The subsequent metabolites or derivatives are commonly less bioactive than the parent compound, however, some of the derivatives were reported to be of higher bioactivity. The physicochemical parameters of the degradation product are also different from the parent pesticide molecules, their fate and significance are also altered with the structural changes. Example of degradative pathways of some pesticides by microbes can by explained as follows (Fig. 3 and 4).

Cell immobilization for efficient pesticide degradation

Immobilized microbial cell means a living microbial cell that is entrapped from moving freely from its original position to other parts or a localization of microbial cells to a certain area or space by maintaining their metabolic as well as catabolic activity. Immobilization of microbial cell may increases the efficacy of the cultures by optimizing the degradation rate of pollutants (Dominguez-Velez and MerinoCastro, 2011). Cell immobilization techniques can be categorized as either organic or inorganic based on their chemical composition, it can also be subdivided into natural or synthetic polymers example starch, agarose, agar, cellulose, alginate, clay, aluminum oxide, hydroxyapatite, ceramic, activated carbon, chitin, collagen, activated pumice polyacrylamide, dextran and keratin. For pesticides degradation, it is essential to explore a for immobilization matrices with appropriate characteristics and physical structure as well as easiness of washing and the likelihoods of using it repeatedly (Talwar and Ninnekar, 2015). Cell immobilization is one the effective biological method for removal of pollutants due to 
TABLE 5. Fungal specie used for degradation of pesticides

\begin{tabular}{|c|c|c|c|}
\hline Compound & Fungal Specie used & Nature of Study & References \\
\hline Dieldrin & PenicilliumMiczynskii & Transformation & (Birolli et al., 2015) \\
\hline Methyl Parathion & AspergillusSydowii & $\begin{array}{l}\text { Degradation, Me- } \\
\text { tabolites }\end{array}$ & (N. Alvarenga et al., 2014) \\
\hline Methyl Parathion & PenicilliumDecaturense & $\begin{array}{l}\text { Degradation, Me- } \\
\text { tabolites }\end{array}$ & (N. Alvarenga et al., 2014) \\
\hline Clothianidin & PhanerochaeteSordida & $\begin{array}{l}\text { Degradation, } \\
\text { Metabolites }\end{array}$ & (Mori et al., 2017) \\
\hline $\begin{array}{l}(\text { Alpha }+ \text { Beta }) \text { Endo- } \\
\text { sulfan }\end{array}$ & BjerkanderaAdusta & $\begin{array}{l}\text { Dissipation/ } \\
\text { Metabolites }\end{array}$ & $\begin{array}{c}\text { (Rivero, Niell, Cesio, Cerdeiras } \\
\text { and Heinzen, 2012) }\end{array}$ \\
\hline $\begin{array}{l}\text { Lindane, Chlordane And } \\
\text { Methoxychlor }\end{array}$ & Streptomyces Consortium & Degradation & $\begin{array}{l}\text { (Fuentes, Raimondo, Amoroso } \\
\text { and Benimeli, 2017) }\end{array}$ \\
\hline $\begin{array}{l}\text { Imiprothrin, } \\
\text { Cypermethrin, } \\
\text { Carbofuran }\end{array}$ & TrametesVersicolor & $\begin{array}{l}\text { Transformation } \\
\text { Metabolite }\end{array}$ & (Mir-Tutusaus et al., 2014) \\
\hline DDT & $\begin{array}{l}\text { GloeophyllumTrabeum, } \\
\text { FomitopsisPinicola }\end{array}$ & $\begin{array}{l}\text { Degradation, } \\
\text { Metabolites }\end{array}$ & $\begin{array}{c}\text { (Purnomo, Mori, Takagi and } \\
\text { Kondo, 2011) }\end{array}$ \\
\hline $\begin{array}{l}\beta \text {-Cypermethrin, } \\
\text { Deltamethrin }\end{array}$ & Cladosporium & $\begin{array}{c}\text { Degradation, } \\
\text { Metabolite, Kinetics }\end{array}$ & (S. Chen et al., 2011)2011 \\
\hline Aldrin, Dieldrin & Phlebia sp. & $\begin{array}{c}\text { Degradation, } \\
\text { Metabolic Pathways }\end{array}$ & (Xiao et al., 2011) \\
\hline DDT & Gloeophyllum,Trabeum & Transformation & $\begin{array}{l}\text { (Purnomo, Kamei and Kondo, } \\
\text { 2008) }\end{array}$ \\
\hline DDT & PhanerochaeteChrysosporium & Degradation & (Zheng, Selvam and Wong, 2012) \\
\hline DDT & XerocomusChrysenteron & $\begin{array}{c}\text { Degradation, } \\
\text { Mineralization And } \\
\text { Metabolite }\end{array}$ & (Huang and Wang, 2013) \\
\hline Aldrin,Dieldrin & PleurotusOstreatus & $\begin{array}{l}\text { Transformation, } \\
\text { Metabolite }\end{array}$ & (Purnomo et al., 2017) \\
\hline $\begin{array}{c}\text { Heptachlor } \\
\text { Heptachlor Epoxide }\end{array}$ & PleurotusOstreatus & $\begin{array}{l}\text { Transformation, } \\
\text { Metabolite }\end{array}$ & $\begin{array}{c}\text { (Purnomo, Putra, Shimizu and } \\
\text { Kondo, 2014) }\end{array}$ \\
\hline $\begin{array}{l}\text { Ensulphuron-Methyl } \\
\qquad \text { (BSM) }\end{array}$ & PenicilliumPinophilum & $\begin{array}{l}\text { Degradation, } \\
\text { Metabolites }\end{array}$ & (Xingxing Peng et al., 2012) \\
\hline Penoxsulam & Aspergius sp. & $\begin{array}{l}\text { Degradation, } \\
\text { Metabolites }\end{array}$ & $\begin{array}{c}\text { (Sondhia, Rajput, Varma and } \\
\text { Kumar, 2016) }\end{array}$ \\
\hline Metribuzin & PleurotusMutilus & Adsorption & $\begin{array}{c}\text { (Behloul, Lounici, Abdi, } \\
\text { Drouiche and Mameri, 2017) }\end{array}$ \\
\hline$\beta$-Cypermethrin & Aspergillus Niger & $\begin{array}{l}\text { Degradation, } \\
\text { Metabolites }\end{array}$ & (Deng et al., 2015) \\
\hline $\begin{array}{l}\text { Chlorotoluron,Diuron, } \\
\text { Isoproturon and Linuron }\end{array}$ & Mortierella $s p$ & $\begin{array}{l}\text { Transformation } \\
\text { Metabolites }\end{array}$ & (Badawi et al., 2009) \\
\hline
\end{tabular}

J. Sus. Agric. Sci. 44, No. 2 (2018) 
acceleration of metabolic activity of the microbial cells by the immobilization matrix (Shah and Naqvi, 2017). The immobilized cells have several advantages over free cells like higher metabolic action, higher mechanical capability as well as tolerant to toxic chemicals due to higher biomass concentrations. Cell immobilization may escalate the survival and metabolic activity of the microbial cells in bioremediation approaches (Tao and Yang, 2011). Previous literatures have advocated that the higher efficiency of immobilized cells results from cellular or genetic variations induced by the immobilization. Immobilized cells are unaffected by distresses in the environment and are less disposed to poisonous materials, which makes immobilized cell attractive for remediation of organic compounds such as pesticides (Engler and Wild, 2009). The biological approaches for the treatments of pollutants have attracted increase attention to be a promising alternative for the removal of pesticides and other pollutants present in the environment (Es et al., 2016; Wang and Wu, 2017). Recently, the entrapment of the cells in gellan gum, calcium alginate, polyacrylonitrilehas agarose, polyamide, polyvinyl alcohol, polyurethane as well as polypropylene were recommended as promising method for microbial degradation of contaminants (Paisio et al., 2016; Talwar and Ninnekar, 2015). The immobilized mediums were non-toxic to the viable cells and low-cost as well as better stability. The approach for effective immobilization is dependent on the concentration of the cell (Gaikwad and Pundle, 2017) Table 6 and 7 shows different mobilized matrix used for the degradation of pesticides and other chemicals.

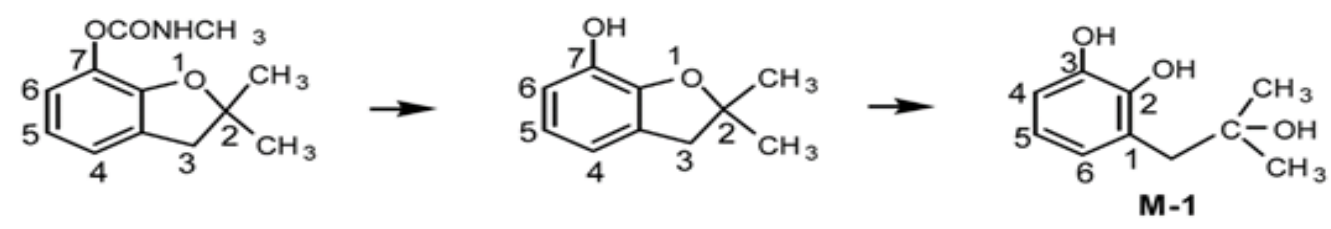

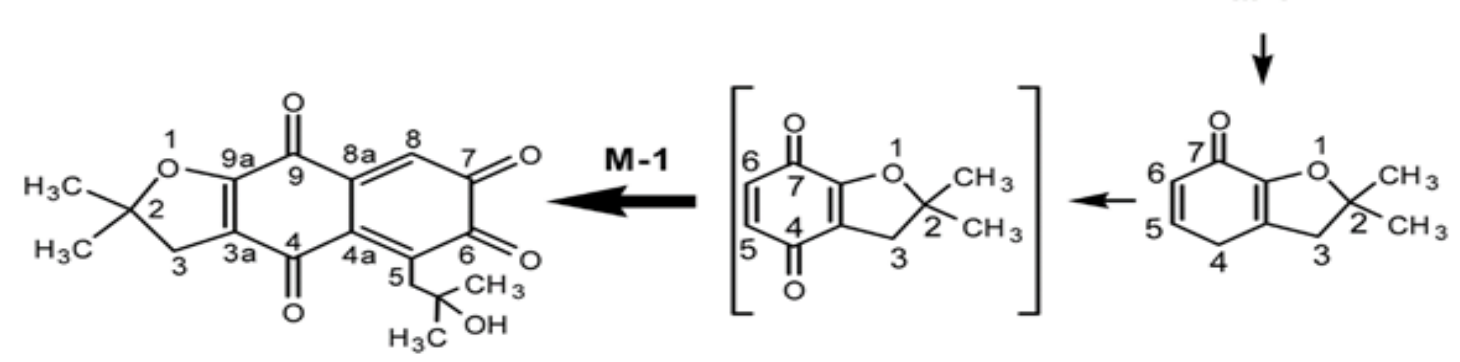

Red metabolite

Fig.3. Proposed degradation pathway of carbofuran by Sphingomonas sp. strain SB5 (Park et al., 2006)<smiles>CC(C)CC1CC(Cl)C(Cl)C(Cl)C1Cl</smiles>

Fig. 4. Proposed pathway for lindane biodegradation by various enriched bacterial isolates (Krishna and Philip, 2008) 
Molecular methods for the degradation of pesticides

Microbes have the capability to degrade multiplicity of environmental pollutants, including pesticides. It is highly significant to understand the biochemical bases for the development of new degaradative capacities of microorganisms involve in pesticide degradation (Quintero-Hernandez and Munoz-Rojas, 2017). Genetic components like the plasmid and transposons were ascertain to have encode enzymes responsible for several pesticides degradation. The isolation and characterization of gene encoding pesticides degradative enzymes as well as novel procedures for isolating and analysis of nucleic acid from microorganisms, would display some distinctive insight into the molecular actions that lead to advance of pesticides degradation phenomena (Chakraborty and Das, 2016). Genetic manipulation offers a technique of engineering microbes to depollute many compounds, including pesticides that may be present in the polluted areas. The main approach is to prolong the degradative abilities of existing metabolic pathways in the organism either by introducing additional enzymes from other organisms or by modifying the already present catabolic genes. Degradation of pesticide by microorganism involves several forms of enzymes. These approaches are based on several kinds of genes coded with plasmid or chromosomal DNA (Chakraborty and Das, 2016). Pesticide degrading genes in microorganisms have were described to be located on plasmids, transposons or chromosomes of the organism. Recent researches have shown the way that lead to development of degradative pathways and the organization of catabolic genes, hence making it simpler to develop genetically modified organisms (GMO) for pesticide degradation. The genetically engineered microbes have substantial capacity to degrade the pesticide as they discharge several specific enzymes that have the specific catabolic gene into plasmids (Chen and Huang, 2016). The studies of recombinant DNA provide the means to develop DNA and RNA examinations for the purpose of identifying microorganisms from diverse populations with exceptional capacity to degrade pesticides

TABLE 6. Immobilized microbial cells used for degradation of pesticides

\begin{tabular}{|c|c|c|c|}
\hline Pesticides & Microbes used & Immobilization matrix & References \\
\hline Carbazole & Sphingomonas sp. & Gellin gum & (Ahmad, 2010) \\
\hline Chlorpyrifos & Streptomyces Sp. & & (Fuentes et al., 2013) \\
\hline Cypermethrin & Micrococcus sp. & Polyurethanefoam (PUF) & (Tallur et al., 2015) \\
\hline Carbofuran & Pseudomonas fluorescens & Ca-alginate & $\begin{array}{l}\text { (X. Wang, Liu, Yao, Zhang } \\
\text { and Bao, 2017) }\end{array}$ \\
\hline Methyl parathion & Consortium & Loofa sponge & (Ahmad, 2010) \\
\hline Coumaphos & Consortium & Loofa sponge & (Ahmad, 2010) \\
\hline $\begin{array}{l}\text { 2,4-D(2,4-dichloro-phenoxy } \\
\text { acetic acid) }\end{array}$ & Pseudomonas fluorescens & Alginate beads & $\begin{array}{l}\text { (Ahmad, 2010; Boivin, } \\
\text { Amellal, Schiavon and van } \\
\text { Genuchten, 2005) }\end{array}$ \\
\hline Aldicarb & $\begin{array}{c}\text { Enterobactr } \\
\text { cloacae }\end{array}$ & Agar entrapment & (Fareed et al., 2017) \\
\hline Carbofuran & Enterobacter cloacae & Agar entrapment & (Fareed et al., 2017) \\
\hline Carbaryl & Enterobacter cloacae & Agar entrapment & (Fareed et al., 2017) \\
\hline \multirow[t]{2}{*}{ Profenofos } & & & (Talwar and Ninnekar, 2015) \\
\hline & Pseudoxanthomonas & Sodium alginate & \\
\hline Endosulfan & Pseudomonas aeruginosa & Ca-alginate & $\begin{array}{l}\text { (Pradeep and Subbaiah, } \\
\text { 2016) }\end{array}$ \\
\hline Atrazine & Pseudomonas sp. & Sodium alginate & $\begin{array}{l}\text { (A. Kumar, Nain and Singh, } \\
\text { 2017) }\end{array}$ \\
\hline Atrazine & Burkholderia sp. & Sodium alginate & (A. Kumar et al., 2017) \\
\hline Endosulfan & Pseudomonas sp. & Ca-alginate & $\begin{array}{l}\text { (Pradeep and Subbaiah, } \\
\text { 2016) }\end{array}$ \\
\hline Quinalphos, & Staphylococcus sp. & Ca-alginate & (Punitha and Rose, 2018) \\
\hline Monocrotophos & Staphylococcus sp. & Ca-alginate & (Punitha and Rose, 2018) \\
\hline Chlorpyriphos & Staphylococcus sp. & Ca-alginate & (Punitha and Rose, 2018) \\
\hline Pendimethalin & Bacillus lehensis & Ca-alginate & $\begin{array}{l}\text { (More, Tallur, Niyonzima } \\
\text { and More, 2015) }\end{array}$ \\
\hline
\end{tabular}


TABLE 7. Immobilized Microbial Cells Used For Degradation of other Pollutants

\begin{tabular}{|c|c|c|c|}
\hline Pollutants & Microorganism & Immobilized bead & References \\
\hline Acrylamide & $\begin{array}{l}\text { Pseudomonas } \\
\text { aeruginosa }\end{array}$ & Ca-alginate & Prabu and Thatheyu, 2007 \\
\hline Azo dye & $\begin{array}{l}\text { Pseudomonas } \\
\text { fluorescens }\end{array}$ & PVA-alginate & Caiet al., 2011 \\
\hline TextileEffluent (dyes) & $\begin{array}{l}\text { Phanerochaete } \\
\text { chrysosporium }\end{array}$ & PVA-alginate & Nasiret al., 2011 \\
\hline $\mathrm{Cd}$ & $\begin{array}{l}\text { Pseudomonas } \\
\text { fluorescens }\end{array}$ & Ca-alginate & Sarin and Sarin, 2010 \\
\hline $\mathrm{Cd}$ & Pseudomonas sp. & Ca-alginate & Rani et al., 2010 \\
\hline Hydrocarbon & Consortium & Ca-alginate & Rahmanet al., 2006 \\
\hline Pesticide & Consortium & Ca-alginate & На, 2005 \\
\hline$\wedge \mathrm{PAH}$ & Sphingomonas sp. & Gellan gum & Wang et al., 2007a. \\
\hline SDS & $\begin{array}{c}\text { Pseudomonas aeruginosa } \\
\text { sp. }\end{array}$ & Gellan gum & Mahmoodet al., 2010 \\
\hline
\end{tabular}

\section{Conclusion}

The extensive use of pesticides leads to contamination of the environment. The advances in biochemical and genetic techniques has expanded the potential for new developments in biodegradation in that it has become practical to isolate and modify potentially useful genes responsible for biodegradation from a wide range of microbes. Plentiful microbes with novel pesticide degradation activities are characterized, biological degradation by microbes can efficiently remediate pesticides from the environment. The ability of these organisms to remove organic pollutants such as pesticides is directly related to their long-term adaptation to the areas where these compounds exist therefore, these microbes that occupy polluted areas are armed with resistance mechanisms to remove the toxic compounds. Furthermore, genetic engineering may be used to enhance the performance of such microbes that have the properties, essential for bioremediation. Microorganisms contribute considerably for the removal of toxic pesticides applied to agricultural field effective microbial consortia need to be grown in large quantity for large scale field application.

\section{References}

Acharya, K. P., Shilpkar, P., Shah, M. C. and Chellapandi, P. (2015) Biodegradation of insecticide monocrotophos by Bacillus subtilis KPA-1, isolated from agriculture soils. Appl Biochem Biotechnol, 175 (4), 1789-1804. doi:10.1007/s12010-0141401-5.
Ahmad, S. W. S. T. M. (2010) Suitability of Immobilized Pseudomonas fluorescens SM1 Strain for Remediation of Phenols, Heavy Metals, and Pesticides from Water. Water Air Soil Pollution, 30 (1) (51-63). doi: DOI 10.1007/s11270-010-0737-x.

Akbar, S. and Sultan, S. (2016) Soil bacteria showing a potential of chlorpyrifos degradation and plant growth enhancement. Braz. J. Microbiol. 47(3), 563-570. doi:10.1016/j.bjm.2016.04.009.

Akbar, S., Sultan, S. and Kertesz, M. (2015) Bacterial community analysis of cypermethrin enrichment cultures and bioremediation of cypermethrin contaminated soils. J. Basic Microbiol. 55 (7), 819829. doi:10.1002/jobm.201400805.

Akoijam, R. and Singh, B. (2014) Metabolic degradation of imidacloprid in paddy field soil. Environ. Monit. Assess. 186(10), 5977-5984. doi:10.1007/s10661014-3833-3.

Alekseeva, T., Prevot, V., Sancelme, M., Forano, C., and Besse-Hoggan, P. (2011) Enhancing atrazine biodegradation by Pseudomonas sp. strain ADP adsorption to Layered Double Hydroxide bionanocomposites. J. Hazard Mater. 191 (1-3), 126-135. doi:10.1016/j. jhazmat. 2011.04.050

Almeida-Gonzalez, M., Luzardo, O. P., Zumbado, M., Rodriguez-Hernandez, A., Ruiz-Suarez, N., Sangil, M., . . . Boada, L. D. (2012) Levels of organochlorine contaminants in organic and conventional cheeses and their impact on the health of consumers: an independent study in the Canary Islands (Spain). Food Chem. Toxicol. 50(12), 43254332. doi:10.1016/j.fct.2012.08.058. 
Alvarenga, N., Birolli, W. G., Meira, E. B., Lucas, S. C., de Matos, I. L., Nitschke, M., . . . Porto, A. L. (2018) Biotransformation and biodegradation of methyl parathion by Brazilian bacterial strains isolated from mangrove peat. Biocatalysis and Agricultural Biotechnology , 13, 319-326, 2018.

Alvarenga, N., Birolli, W. G., Seleghim, M. H., and Porto, A. L. (2014) Biodegradation of methyl parathion by whole cells of marine-derived fungi Aspergillus sydowii and Penicillium decaturense. Chemosphere 117, 47-52. doi:10.1016/j. chemosphere. 2014.05. 069.

Anderson, B., Phillips, B., Hunt, J., Largay, B., Shihadeh, R. and Tjeerdema, R. (2011) Pesticide and toxicity reduction using an integrated vegetated treatment system. Environ Toxicol Chem, 30 (5), 1036-1043. doi:10.1002/etc.471.

André Luiz Meleiro Porto, G. Z. M., Nitschke, M. C. K. a. M. and Universidade de São Paulo, I. d. Q. d. S. C. (2011), Biodegradation of Pesticides, 7, 307.

Anhalt, J. C., Moorman, T. B. and Koskinen, W. C. (2007) Biodegradation of imidacloprid by an isolated soil microorganism. J. Environ. Sci. Health B, 42 (5), 509-514. doi:10.1080/03601230701391401.

Anusha, J., Kavitha, P., Louella, C., Chetan, D. and Rao, C. (2009) A study on biodegradation of propoxur by bacteria isolated from municipal solid waste. International Journal of Biotechnology Applications, 1 (2), 26-31.

Aparicio, J., Sola, M. Z., Benimeli, C. S., Amoroso, M. J. and Polti, M. A. (2015) Versatility of Streptomyces sp. M7 to bioremediate soils co-contaminated with $\mathrm{Cr}(\mathrm{VI})$ and lindane. Ecotoxicol. Environ. Saf. 116, 34-39. doi:10.1016/j.ecoenv. 2015.02.036.

Arias-Estévez, M., López-Periago, E., MartínezCarballo, E., Simal-Gándara, J., Mejuto, J.-C., and García-Río, L. (2008) The mobility and degradation of pesticides in soils and the pollution of groundwater resources. Agriculture, Ecosystems \& Environment, 123 (4), 247-260.

Aust, S. D. and Benson, J. T. (1993) The fungus among us: use of white rot fungi to biodegrade environmental pollutants. Environ. Health Perspect. 101(3), 232-233.

Avinash, V. S., Chauhan, P. D., Gaikwad, S. and Pundle, A. (2017) Biotransformation of penicillin V to 6-aminopenicillanic acid using immobilized whole cells of E. coli expressing a highly active penicillin V acylase. Prep. Biochem. Biotechnol. 47(1), 5257. doi:10.1080/10826068.2016.1163580.
Azadi, D., Shojaei, H., Mobasherizadeh, S. and Naser, A. D. (2017) Screening, isolation and molecular identification of biodegrading mycobacteria from Iranian ecosystems and analysis of their biodegradation activity. AMB Express, 7(1), 180. doi:10.1186/s13568-017-0472-4.

Azmy, A. F., Saafan, A. E., Essam, T. M., Amin, M. A., and Ahmed, S. H. (2015) Biodegradation of Malathion by Acinetobacter baumannii Strain AFA Isolated from Domestic Sewage in Egypt. Biodegradation, 117465.

Azubuike, C. C., Chikere, C. B., and Okpokwasili, G. C. (2016) Bioremediation techniques-classification based on site of application: principles, advantages, limitations and prospects. World J. Microbiol. Biotechnol. 32 (11), 180. doi:10.1007/s11274-0162137-x.

Badawi, N., Ronhede, S., Olsson, S., Kragelund, B. B., Johnsen, A. H., Jacobsen, O. S. and Aamand, J. (2009) Metabolites of the phenylurea herbicides chlorotoluron, diuron, isoproturon and linuron produced by the soil fungus Mortierella sp. Environ. Pollut. 157 (10), 2806-2812. doi:10.1016/j. envpol.2009.04.019.

Badii, M. and Landeros, J. (2007) Cuantificación de la fragmentación del paisaje y su relación con Sustentabilidad.

Baez-Rogelio, A., Morales-Garcia, Y. E., QuinteroHernandez, V. and Munoz-Rojas, J. (2017) Next generation of microbial inoculants for agriculture and bioremediation. Microb. Biotechnol. 10 (1), 1921. doi:10.1111/1751-7915.12448.

Bajaj, S., Sagar, S., Khare, S. and Singh, D. K. (2017) Biodegradation of $\gamma$-hexachlorocyclohexane (lindane) by halophilic bacterium Chromohalobacter sp. LD2 isolated from $\mathrm{HCH}$ dumpsite. International Biodeterioration and Biodegradation, 122, 23-28.

Bano, N., and Musarrat, J. (2004) Characterization of a novel carbofuran degrading Pseudomonas sp. with collateral biocontrol and plant growth promoting potential. FEMS Microbiol. Lett. 231(1), 13-17. doi:10.1016/S0378-1097(03)00894-2.

Barriada-Pereira, M., Gonzalez-Castro, M. J., MuniateguiLorenzo, S., Lopez-Mahia, P., Prada-Rodriguez, D., and Fernandez-Fernandez, E. (2005) Organochlorine pesticides accumulation and degradation products in vegetation samples of a contaminated area in Galicia (NW Spain). Chemosphere, 58 (11), 1571-1578. doi:10.1016/j.chemosphere. 2004.10.016.

J. Sus. Agric. Sci. 44, No. 2 (2018) 
Behloul, M., Lounici, H., Abdi, N., Drouiche, N., and Mameri, N. (2017) Adsorption study of metribuzin pesticide on fungus Pleurotus mutilus. International Biodeterioration \& Biodegradation, 119, 687-695. doi:https://doi.org/10.1016/j.ibiod. 2016.07.005.

Bending, G. D., Friloux, M. and Walker, A. (2002) Degradation of contrasting pesticides by white rot fungi and its relationship with ligninolytic potential. FEMS Microbiol. Lett. 212(1), 59-63.

Bermudez-Couso, A., Novoa-Munoz, J. C., AriasEstevez, M. and Fernandez-Calvino, D. (2013) Influence of different abiotic and biotic factors on the metalaxyl and carbofuran dissipation. Chemosphere, 90(10), 2526-2533. doi:10.1016/j. chemosphere. 2012.10.090.

Bernstein, A., Adar, E., Nejidat, A. and Ronen, Z. (2011) Isolation and characterization of RDX-degrading Rhodococcus species from a contaminated aquifer. Biodegradation, 22 (5), 997-1005. doi:10.1007/ s10532-011-9458-0.

Birolli, W. G., Yamamoto, K. Y., de Oliveira, J. R., Nitschke, M., Seleghim, M. H., and Porto, A. L. (2015) Biotransformation of dieldrin by the marine fungus Penicillium miczynskii CBMAI 930. Biocatalysis and Agricultural Biotechnology, 4(1), $39-43$.

Blume, H. P., and Ahlsdorf, B. (1993) Prediction of pesticide behavior in soil by means of simple field tests. Ecotoxicol. Environ. Saf. 26 (3), 313-332. doi:10.1006/eesa.1993.1060.

Boada, L. D., Henriquez-Hernandez, L. A., Zumbado, M., Almeida-Gonzalez, M., Alvarez-Leon, E. E., Navarro, P., and Luzardo, O. P. (2016) Organochlorine Pesticides Exposure and Bladder Cancer: Evaluation from a Gene-Environment Perspective in a Hospital-Based Case-Control Study in the Canary Islands (Spain). J. Agromedicine, 21 (1), 34-42. doi:10.1080/1059924X.2015.1106374.

Boivin, A., Amellal, S., Schiavon, M., and van Genuchten, M.T.(2005)2,4-Dichlorophenoxyacetic acid (2,4-D) sorption and degradation dynamics in three agricultural soils. Environ. Pollut. 138(1), 9299. doi:10.1016/j.envpol.2005.02.016.

Brogan, W. R., 3rd, and Relyea, R. A. (2017) Multiple mitigation mechanisms: Effects of submerged plants on the toxicity of nine insecticides to aquatic animals. Environ. Pollut. 220 (Pt A), 688-695. doi:10.1016/j.envpol.2016.10.030.

Castro-Gonzalez, A., Prieto-Jimenez, D., Dominguez-
Velez, A., and Merino-Castro, G. (2011) Biological degradation of simazine by mixed-microbial cultures immobilized on sepiolite and tepojal beads. Water Environ. Res. 83 (3), 274-288.

Chakraborty, J. and Das, S. (2016) Molecular perspectives and recent advances in microbial remediation of persistent organic pollutants. Environ. Sci. Pollut. Res. Int. 23 (17), 1688316903. doi:10.1007/s11356-016-6887-7.

Chanika, E., Georgiadou, D., Soueref, E., Karas, P., Karanasios, E., Tsiropoulos, N. G., ... Karpouzas, D. G. (2011) Isolation of soil bacteria able to hydrolyze both organophosphate and carbamate pesticides. Bioresour. Technol. 102 (3), 3184-3192. doi:10.1016/j.biortech.2010.10.145.

Chattopadhyay, P., Banerjee, G., and Mukherjee, S. (2017) Recent trends of modern bacterial insecticides for pest control practice in integrated crop management system. 3 Biotech. 7 (1), 60. doi:10.1007/s13205-017-0717-6.

Chauhan, A., and Singh, J. (2015) Biodegradation of DDT. J. Textile Sci. Eng. 5, 183.

Chen, S., Deng, Y., Chang, C., Lee, J., Cheng, Y., Cui, Z. and Zhang, L. H. (2015) Pathway and kinetics of cyhalothrin biodegradation by Bacillus thuringiensis strain ZS-19. Sci. Rep. 5, 8784. doi:10.1038/srep08784.

Chen, S., Hu, M., Liu, J., Zhong, G., Yang, L., Rizwanul-Haq, M. and Han, H. (2011) Biodegradation of beta-cypermethrin and 3-phenoxybenzoic acid by a novel Ochrobactrum lupini DG-S-01. Journal of Hazardous Materials, 187 (1-3), 433-440.

Chen, S., Hu, Q., Hu, M., Luo, J., Weng, Q., and Lai, K. (2011) Isolation and characterization of a fungus able to degrade pyrethroids and 3-phenoxybenzaldehyde. Bioresour. Technol. 102 (17), 8110-8116. doi:10.1016/j.biortech. 2011.06.055

Chen, S., Lai, K., Li, Y., Hu, M., Zhang, Y. and Zeng, Y. (2011) Biodegradation of deltamethrin and its hydrolysis product 3-phenoxybenzaldehyde by a newly isolated Streptomyces aureus strain HP-S01. Applied Microbiology and Biotechnology, 90 (4), 1471-1483.

Coelho-Moreira Jda, S., Bracht, A., de Souza, A. C., Oliveira, R. F., de Sa-Nakanishi, A. B., de Souza, C. G. and Peralta, R. M. (2013) Degradation of diuron by Phanerochaete chrysosporium: role of ligninolytic enzymes and cytochrome P450. Biomed. 
Res. Int. 2013, 251354. doi:10.1155/2013/251354.

Cycoń, M., Żmijowska, A., and Piotrowska-Seget, Z. (2014) Enhancement of deltamethrin degradation by soil bioaugmentation with two different strains of Serratia marcescens. International Journal of Environmental Science and Technology, 11 (5), 13051316.

Dechesne, A., Badawi, N., Aamand, J., and Smets, B. F. (2014) Fine scale spatial variability of microbial pesticide degradation in soil: scales, controlling factors, and implications. Front Microbiol. 5, 667. doi:10.3389/fmicb.2014.00667.

Deng, W., Lin, D., Yao, K., Yuan, H., Wang, Z., Li, J., . . . Liu, S. (2015) Characterization of a novel betacypermethrin-degrading Aspergillus niger YAT strain and the biochemical degradation pathway of betacypermethrin. Appl. Microbiol. Biotechnol. 99 (19), 8187-8198. doi:10.1007/s00253-015-6690-2.

Deshmukh, R., Khardenavis, A. A. and Purohit, H. J. (2016) Diverse Metabolic Capacities of Fungi for Bioremediation. Indian J. Microbiol. 56(3), 247-264. doi:10.1007/s12088-016-0584-6.

Doddamani, H. P., and Ninnekar, H. Z. (2001) Biodegradation of carbaryl by a Micrococcus species. Curr. Microbiol. 43 (1), 69-73. doi:10.1007/ s002840010262.

Dua, M., Singh, A., Sethunathan, N. and Johri, A. K. (2002) Biotechnology and bioremediation: successes and limitations. Appl. Microbiol. Biotechnol. 59 (2-3), 143-152. doi:10.1007/s00253002-1024-6.

Edwards, D. E., Kremer, R. J., and Keaster, A. J. (1992) Characterization and growth response of bacteria in soil following application of carbofuran. J. Environ. Sci. Health B, 27 (2), 139-154. doi:10.1080/03601239209372771.

Erdem, Z., and Cutright, T. J. (2016) Biodegradation Potential of 1, 1, 1-Trichloro-2, 2-Bis (p-Chlorophenyl) Ethane (4, 4'-DDT) on a SandyLoam Soil Using Aerobic Bacterium Alcaligenes eutrophus A5. Environmental Engineering Science, 33 (3), 149-159.

Es, I., Ribeiro, M. C., Dos Santos Junior, S. R., Khaneghah, A. M., Rodriguez, A. G. and Amaral, A. C. (2016) Production of cyclodextrin glycosyltransferase by immobilized Bacillus sp. on chitosan matrix. Bioprocess Biosyst Eng, 39(10), 1487-1500. doi:10.1007/s00449-016-1625-6.

Fang, H., Cai, L., Yang, Y., Ju, F., Li, X., Yu, Y. and J. Sus. Agric. Sci. 44, No. 2 (2018)
Zhang, T. (2014) Metagenomic analysis reveals potential biodegradation pathways of persistent pesticides in freshwater and marine sediments. Sci Total Environ. 470-471, 983-992. doi:10.1016/j. scitotenv.2013.10.076.

Fang, H., Wang, Y., Gao, C., Yan, H., Dong, B., and Yu, Y. (2010) Isolation and characterization of Pseudomonas sp. CBW capable of degrading carbendazim. Biodegradation, 21(6), 939-946. doi:10.1007/s10532-010-9353-0.

Fareed, A., Zaffar, H., Rashid, A., Maroof Shah, M., and Naqvi, T. A. (2017) Biodegradation of $\mathrm{N}$-methylated carbamates by free and immobilized cells of newly isolated strain Enterobacter cloacae strain TA7. Bioremediation Journal, 1-9.

Fernández-López, M. G., Popoca-Ursino, C., SánchezSalinas, E., Tinoco-Valencia, R., Folch-Mallol, J. L., Dantán-González, E., and Laura Ortiz-Hernández, M. (2017) Enhancing methyl parathion degradation by the immobilization of Burkholderia sp. isolated from agricultural soils. Microbiologyopen, 6 (5).

Fournier, D., Halasz, A., Spain, J., Spanggord, R. J., Bottaro, J. C., and Hawari, J. (2004) Biodegradation of the hexahydro-1,3,5-trinitro-1,3,5-triazine ring cleavage product 4-nitro-2,4-diazabutanal by Phanerochaete chrysosporium. Appl. Environ. Microbiol. 70 (2), 1123-1128.

Fuentes, M. S., Briceno, G. E., Saez, J. M., Benimeli, C. S., Diez, M. C., and Amoroso, M. J. (2013) Enhanced removal of a pesticides mixture by single cultures and consortia of free and immobilized Streptomyces strains. Biomed. Res. Int. 2013, 392573. doi:10.1155/2013/392573.

Fuentes, M. S., Raimondo, E. E., Amoroso, M. J. and Benimeli, C. S. (2017) Removal of a mixture of pesticides by a Streptomyces consortium: Influence of different soil systems. Chemosphere, 173, 359367. doi:10.1016/j.chemosphere.2017.01.044.

Garbisu, C., Hernandez-Allica, J., Barrutia, O., Alkorta, I. and Becerril, J. M. (2002) Phytoremediation: a technology using green plants to remove contaminants from polluted areas. Rev. Environ. Health, 17 (3), 173-188.

Ha, J., Engler, C. R. and Wild, J. R. (2009) Biodegradation of coumaphos, chlorferon, and diethylthiophosphate using bacteria immobilized in Ca-alginate gel beads. Bioresour. Technol. 100 (3), 1138-1142. doi:10.1016/j.biortech.2008.08.022.

Hamada, M., Matar, A., and Bashir, A. (2015) 
Carbaryl degradation by bacterial isolates from a soil ecosystem of the Gaza Strip. Braz. J. Microbiol. 46 (4), 1087-1091. doi:10.1590/S1517838246420150177 .

Henderson, K. L., Belden, J. B., Zhao, S. and Coats, J. R. (2006) Phytoremediation of pesticide wastes in soil. Z Naturforsch C, 61 (3-4), 213-221.

Huang, Y., \& Wang, J. (2013) Degradation and mineralization of DDT by the ectomycorrhizal fungi, Xerocomus chrysenteron. Chemosphere, 92 (7), 760-764. doi:10.1016/j.chemosphere.2013.04.002.

Ishag, A. E., Abdelbagi, A. O., Hammad, A. M., Elsheikh, E. A., Elsaid, O. E., Hur, J. H., and Laing, M. D. (2016) Biodegradation of Chlorpyrifos, Malathion, and Dimethoate by Three Strains of Bacteria Isolated from Pesticide-Polluted Soils in Sudan. J. Agric. Food Chem. 64 (45), 8491-8498. doi:10.1021/acs.jafc.6b03334.

Jacobsen, R. E., Fantke, P., and Trapp, S. (2015) Analysing half-lives for pesticide dissipation in plants. SAR QSAR Environ. Res. 26 (4), 325-342. doi:10.1080/1062936X.2015.1034772.

Jacquet, P., Daude, D., Bzdrenga, J., Masson, P., Elias, M., \& Chabriere, E. (2016) Current and emerging strategies for organophosphate decontamination: special focus on hyperstable enzymes. Environ. Sci. Pollut. Res. Int. 23 (9), 8200-8218. doi:10.1007/ s11356-016-6143-1.

Javaid, M. K., Ashiq, M., and Tahir, M. (2016) Potential of Biological Agents in Decontamination of Agricultural Soil. Scientifica (Cairo), 2016, 1598325. doi:10.1155/2016/1598325.

Jesitha, K., Nimisha, K., Manjusha, C. and Harikumar, P. (2015) Biodegradation of Endosulfan by Pseudomonas fluorescens. Environmental processes, 2(1), 225-240.

Jin, Z., Guo, Q., Zhang, Z., and Yan, T. (2014) Biodegradation of type II pyrethroids and major degraded products by a newly isolated Acinetobacter sp. strain JN8. Can. J. Microbiol. 60 (8), 541-545. doi:10.1139/cjm-2014-0104.

Kadhim, F., Rabee, A. M., and Abdalraheem, E. (2015) Biodegradation of Malathion by Selected Bacterial Isolates. J. Int. Environmental Application \& Science, 10 (3), 361-366.

Kamanavalli, C. and Ninnekar, H. (2000) Biodegradation of propoxur by Pseudomonas species. World Journal of Microbiology and Biotechnology, 16 (4), 329-331.
Karpouzas, D. G., Morgan, J. A., and Walker, A. (2000) Isolation and characterization of 23 carbofurandegrading bacteria from soils from distant geographical areas. Lett. Appl. Microbiol. 31(5), 353-358.

Kataoka, R., Takagi, K., Kamei, I., Kiyota, H., and Sato, Y. (2010) Biodegradation of dieldrin by a soil fungus isolated from a soil with annual endosulfan applications. Environ. Sci. Technol. 44 (16), 6343-6349. doi:10.1021/es1000227.

Kaur, J., Moskalikova, H., Niharika, N., Sedlackova, M., Hampl, A., Damborsky, J., . . . Lal, R. (2013) Sphingobium baderi sp. nov., isolated from a hexachlorocyclohexane dump site. Int. J. Syst. Evol. Microbiol. 63 (Pt 2), 673-678. doi:10.1099/ ijs.0.039834-0.

Kevin Mbogo, O. (2012) Characterization of methomyl and carbofuran degrading-bacteria from soils of horticultural farms in Rift Valley and Central Kenya. African Journal of Environmental Science and Technology, 6 (2). doi:10.5897/ajest11.067.

Khan, S., Zaffar, H., Irshad, U., Ahmad, R., Khan, A. R., Shah, M. M., ... Naqvi, T. (2016) Biodegradation of malathion by Bacillus licheniformis strain ML-1. Archives of Biological Sciences, 68 (1), 51-59.

Kim, H., Kim, D.-U., Lee, H., Yun, J. and Ka, J.-O. (2017) Syntrophic biodegradation of propoxur by Pseudaminobacter sp. SP1a and Nocardioides sp. $\mathrm{SP} 1 \mathrm{~b}$ isolated from agricultural soil. International Biodeterioration \& Biodegradation, 118, 1-9.

Kim, I. S., Ryu, J. Y., Hur, H. G., Gu, M. B., Kim, S. D. and Shim, J. H. (2004) Sphingomonas sp. strain SB5 degrades carbofuran to a new metabolite by hydrolysis at the furanyl ring. J. Agric. Food Chem.52 (8), 2309-2314. doi:10.1021/jf0355021.

Krishna, K. R., and Philip, L. (2008) Biodegradation of lindane, methyl parathion and carbofuran by various enriched bacterial isolates. J. Environ. Sci. Health B, 43 (2), 157-171. doi:10.1080/03601230701795155

Kumar, A., Nain, L., and Singh, N. (2017) Alginate immobilized enrichment culture for atrazine degradation in soil and water system. J. Environ. Sci. Health B, 52 (4), 229-236. doi:10.1080/03601 234.2016.1270680

Kumar, D., Kumar, A., and Sharma, J. (2016) Degradation study of lindane by novel strains Kocuria sp. DAB-1Y and Staphylococcus sp. DAB1W. Bioresources and Bioprocessing, 3 (1), 53.

Kumar Singh, B., Walker, A., and Wright, D. J. (2002) Persistence of chlorpyrifos, fenamiphos,

J. Sus. Agric. Sci. 44, No. 2 (2018) 
chlorothalonil, and pendimethalin in soil and their effects on soil microbial characteristics. Bull Environ Contam Toxicol, 69 (2), 181-188. doi:10.1007/s00128-002-0045-2.

Larkin, M., and Day, M. (1986) The metabolism of carbaryl by three bacterial isolates, Pseudomonas spp.(NCIB 12042 \& 12043) and Rhodococcus sp.(NCIB 12038) from garden soil. Journal of Applied Microbiology, 60(3), 233-242.

Larkin, M. J., and Day, M. J. (1985) The effect of pH on the selection of carbaryl-degrading bacteria from garden soil. J. Appl. Bacteriol. 58 (2), 175-185.

Liu, J., Tan, L., Wang, J., Wang, Z., Ni, H., and Li, L. (2016) Complete biodegradation of chlorpyrifos by engineered Pseudomonas putida cells expressing surface-immobilized laccases. Chemosphere, 157, 200-207. doi:10.1016/j.chemosphere.2016.05.031.

Maheswari Sepperumal, U., Palanimanickam, A., and Sivalingam, G. (2017) Plasmid mediated endosulfan degradation by Bacillus ciradans and Acinetobacter species. Journal of Microbiology and Biotechnology Research, 3 (6), 15-20.

Malik, D., Singh, M., \& Bhatia, P. (2009) Biodegradation of cypermethrin by a Pseudomonas strain Cyp19 and its use in bioremediation of contaminated soil. Int. J. Microbiol, 6 (2).

Mansouri, A., Cregut, M., Abbes, C., Durand, M. J., Landoulsi, A., and Thouand, G. (2017) The Environmental Issues of DDT Pollution and Bioremediation: a Multidisciplinary Review. Appl Biochem.Biotechnol. 181 (1), 309-339. doi:10.1007/s12010-016-2214-5.

Mariana, F., Buchholz, F., Harms, H., Yong, Z., Yao, J., and Maskow, T. (2010) Isothermal titration calorimetry - a new method for the quantification of microbial degradation of trace pollutants. $J$. Microbiol. Methods, 82 (1), 42-48. doi:10.1016/j. mimet.2010.03.024.

Mathew, B. B., Singh, H., Biju, V. G., and Krishnamurthy, N. B. (2017) Classification, Source, and Effect of Environmental Pollutants and Their Biodegradation. J. Environ. Pathol. Toxicol. Oncol. 36 (1), 55-71. doi:10.1615/J. Environ. PatholToxicolOncol.2017015804.

Megharaj, M., Ramakrishnan, B., Venkateswarlu, K., Sethunathan, N., and Naidu, R. (2011) Bioremediation approaches for organic pollutants: a critical perspective. Environ. Int. 37(8), 13621375. doi:10.1016/j.envint.2011.06.003.
Menzie, C. M. (1972) Fate of pesticides in the environment. Annu. Rev. Entomol. 17, 199-222. doi:10.1146/annurev.en.17.010172.001215.

Miglioranza, K. S., de Moreno, J. E., and Moreno, V. J. (2004) Organochlorine pesticides sequestered in the aquatic macrophyte Schoenoplectus californicus (C.A. Meyer) Sojak from a shallow lake in Argentina. Water Res. 38 (7), 1765-1772. doi:10.1016/j.watres.2004.01.017.

Mir-Tutusaus, J. A., Masis-Mora, M., Corcellas, C., Eljarrat, E., Barcelo, D., Sarra, M. and RodriguezRodriguez, C. E. (2014) Degradation of selected agrochemicals by the white rot fungus Trametes versicolor. Sci. Total Environ. 500-501, 235-242. doi:10.1016/j.scitotenv.2014.08.116

Mohanta, M., Saha, A., Zamman, M., Ekram, A., Khan, A., Mannan, S., and Fakruddin, M. (2012). Isolation and characterization of carbofuran degrading bacteria from cultivated soil. Biochem. Cell Arch.12 (2), 313-320.

More, V. S., Tallur, P. N., Niyonzima, F. N. and More, S. S. (2015). Enhanced degradation of pendimethalin by immobilized cells of Bacillus lehensis XJU. 3 Biotech. 5 (6), 967-974.

Mori, T., Wang, J., Tanaka, Y., Nagai, K., Kawagishi, H., and Hirai, H. (2017) Bioremediation of the neonicotinoid insecticide clothianidin by the whiterot fungus Phanerochaete sordida. J. Hazard Mater. 321, 586-590. doi:10.1016/j.jhazmat.2016.09.049

Murugesan, A., Jeyasanthi, T., and Maheswari, S. (2010). Isolation and characterization of cypermethrin utilizing bacteria from Brinjal cultivated soil. African Journal of Microbiology Research, 4(1), 010-013.

Neerja, Grewal, J., Bhattacharya, A., Kumar, S., Singh, D. K., and Khare, S. K. (2016) Biodegradation of 1, 1, 1-trichloro-2, 2-bis (4-chlorophenyl) ethane (DDT) by using Serratia marcescens NCIM 2919. Journal of Environmental Science and Health, Part B, 51(12), 809-816.

Nousiainen, A. O., Bjorklof, K., Sagarkar, S., Nielsen, J. L., Kapley, A., and Jorgensen, K. S. (2015) Bioremediation strategies for removal of residual atrazine in the boreal groundwater zone. Appl Microbiol Biotechnol, 99(23), 10249-10259. doi:10.1007/s00253-015-6828-2.

Onunga, D. O., Kowino, I. O., Ngigi, A. N., Osogo, A., Orata, F., Getenga, Z. M. and Were, H. (2015) Biodegradation of carbofuran in soils within Nzoia 
River Basin, Kenya. J. Environ. Sci. Health B, 50 (6), 387-397. doi:10.1080/03601234.2015.101196 5 .

Paisio, C. E., Talano, M. A., Gonzalez, P. S., Magallanes-Noguera, C., Kurina-Sanz, M. and Agostini, E. (2016) Biotechnological tools to improve bioremediation of phenol by Acinetobacter sp. RTE1.4. Environ. Technol. 37 (18), 2379-2390. doi:10.1080/09593330.2016.1150352.

Pan, X., Lin, D., Zheng, Y., Zhang, Q., Yin, Y., Cai, L., . . . Yu, Y. (2016) Biodegradation of DDT by Stenotrophomonas sp. DDT-1: Characterization and genome functional analysis. Scientific reports, 6, 21332 .

Pannu, R. and Kumar, D. (2017) Process optimization of $\gamma$-Hexachlorocyclohexane degradation using three novel Bacillus sp. strains. Biocatalysis and Agricultural Biotechnology, 11, 97-107.

Park, M. R., Lee, S., Han, T., Oh, B., Shim, J. H., \& Kim, I. S. (2006) A new intermediate in the degradation of carbofuran by Sphingomonas sp. strain SB5. Journal of Microbiology and Biotechnology, 16 (8), 1306.

Pathak, A., Chauhan, A., Ewida, A. Y., and Stothard, P. (2016) Whole Genome Sequence Analysis of an Alachlor and Endosulfan Degrading Micrococcus sp. strain 2385 Isolated from Ochlockonee River, Florida. J Genomics, 4, 42-47. doi:10.7150/ jgen.16156.

Pattanayak, S., Chakraborty, S., Biswas, S., Chattopadhyay, D., and Chakraborty, M. (2018) Degradation of Methyl Parathion, a common pesticide and Fluorescence quenching of Rhodamine B, a carcinogen using $\beta$-D glucan stabilized Gold nanoparticles. Journal of Saudi Chemical Society.

Peng, X., Huang, J., Liu, C., Xiang, Z., Zhou, J., \& Zhong, G. (2012) Biodegradation of bensulphuronmethyl by a novel Penicillium pinophilum strain, BP-H-02. Journal of Hazardous Materials, 213-214, 216-221. doi:https://doi.org/10.1016/j. jhazmat.2012.01.077.

Peng, X., Zhang, J. S., Li, Y. Y., Li, W., Xu, G. M., and Yan, Y. C. (2008) Biodegradation of insecticide carbofuran by Paracoccus sp. YM3. J. Environ. Sci. Health B, 43 (7), 588-594. doi:10.1080/03601230802234492.

Popoca-Ursino, E. C., Martinez-Ocampo, F., DantanGonzalez, E., Sanchez-Salinas, E. and OrtizHernandez, M. L. (2017) Characterization of methyl parathion degradation by a Burkholderia zhejiangensis strain, CEIB S4-3, isolated from agricultural soils. Biodegradation, 28(5-6), 351367. doi:10.1007/s10532-017-9801-1.

Pradeep, V., and Subbaiah, U. M. (2016) Use of Caalginate immobilized Pseudomonas aeruginosa for repeated batch and continuous degradation of Endosulfan. 3 Biotech, 6(2), 124.

Punitha, M. and Rose, J. C. (2018) Biodegradation of organophosphorous pesticide using immobilized esterase and toxicity assessment. Journal of Global Biosciences, 7 (1), 5331-5341.

Purnomo, A. S., Kamei, I. and Kondo, R. (2008) Degradation of 1,1,1-trichloro-2,2-bis (4-chlorophenyl) ethane (DDT) by brown-rot fungi. Journal of Bioscience and Bioengineering, 105(6), 614-621. doi:https://doi.org/10.1263/jbb.105.614.

Purnomo,A. S., Mori, T., Takagi, K. and Kondo, R.(2011) Bioremediation of DDT contaminated soil using brown-rot fungi. International Biodeterioration and Biodegradation, 65 (5), 691-695. doi:https:// doi.org/10.1016/j.ibiod.2011.04.004.

Purnomo, A. S., Nawfa, R., Martak, F., Shimizu, K., \& Kamei, I. (2017) Biodegradation of Aldrin and Dieldrin by the White-Rot Fungus Pleurotus ostreatus. Curr Microbiol, 74 (3), 320-324. doi:10.1007/s00284-016-1184-8.

Purnomo, A. S., Putra, S. R., Shimizu, K. and Kondo, R. (2014) Biodegradation of heptachlor and heptachlor epoxide-contaminated soils by whiterot fungal inocula. Environ. Sci. Pollut. Res. Int. 21 (19), 11305-11312. doi:10.1007/s11356-014-30261.

Quintero, J. C., Moreira, M. T., Feijoo, G. and Lema, J. M. (2008) Screening of white rot fungal species for their capacity to degrade lindane and other isomers of hexachlorocyclohexane (HCH). Ciencia e investigación agraria, 35 (2), 159-167.

Ren, X., Zhang, P., Zhao, L. and Sun, H. (2016) Sorption and degradation of carbaryl in soils amended with biochars: influence of biochar type and content. Environ. Sci. Pollut. Res. Int. 23 (3), 2724-2734. doi:10.1007/s11356-015-5518-z.

Rivero, A., Niell, S., Cesio, V., Cerdeiras, M. P., \& Heinzen, H. (2012) Analytical methodology for the study of endosulfan bioremediation under controlled conditions with white rot fungi. $J$. Chromatogr. B Analyt. Technol. Biomed. Life Sci. 907, 168-172. doi:10.1016/j.jchromb.2012.09.010. 
Rodriguez-Liebana, J. A., Mingorance, M. D. and Pena, A. (2014) Pesticide mobility and leachate toxicity in two abandoned mine soils. Effect of organic amendments. Sci. Total Environ. 497-498, 561-569. doi:10.1016/j.scitotenv.2014.08.010.

Sariwati, A., Purnomo, A. S. and Kamei, I. (2017) Abilities of Co-cultures of Brown-Rot Fungus Fomitopsis pinicola and Bacillus subtilis on Biodegradation of DDT. Curr. Microbiol. 74 (9), 1068-1075. doi:10.1007/s00284-017-1286-y.

Singh, D. K. (2008) Biodegradation and bioremediation of pesticide in soil: concept, method and recent developments. Indian J. Microbiol. 48(1), 35-40. doi:10.1007/s12088-008-0004-7.

Singh, M. and Singh, D. K. (2014) Biodegradation of endosulfan in broth medium and in soil microcosm by Klebsiella sp. M3. Bulletin of Environmental Contamination and Toxicology, 92(2), 237-242.

Singh, T. and Singh, D. K. (2017) Phytoremediation of organochlorine pesticides: Concept, method, and recent developments. Int. J. Phytoremediation, 19 (9), 834-843. doi:10.1080/15226514.2017.1290579.

Sondhia, S., Rajput, S., Varma, R. K., \& Kumar, A. (2016) Biodegradation of the herbicide penoxsulam (triazolopyrimidine sulphonamide) by fungal strains of Aspergillus in soil. Applied Soil Ecology, 105, 196-206. doi:https://doi.org/10.1016/j. apsoil.2016.03.010.

Sukul, P. and Spiteller, M. (2001) Persistence, fate, and metabolism of [(14)C]metalaxyl in typical Indian soils. J. Agric. Food Chem. 49 (5), 2352-2358.

Supreeth, M., and Raju, N. S. (2017) Biotransformation of chlorpyrifos and endosulfan by bacteria and fungi. Appl Microbiol Biotechnol, 101 (15), 59615971. doi:10.1007/s00253-017-8401-7.

Tallur, P. N., Mulla, S. I., Megadi, V. B., Talwar, M. P., and Ninnekar, H. Z. (2015) Biodegradation of cypermethrin by immobilized cells of Micrococcus sp. strain CPN 1. Braz. J. Microbiol. 46 (3), 667672. doi:10.1590/S1517-838246320130557.

Talwar, M. P. and Ninnekar, H. Z. (2015) Biodegradation of pesticide profenofos by the free and immobilized cells of Pseudoxanthomonas suwonensis strain HNM. J. Basic Microbiol. 55(9), 1094-1103. doi:10.1002/jobm.201400978.

Tao, L. and Yang, H. (2011) Fluroxypyr biodegradation in soils by multiple factors. Environ. Monit. Assess. 175 (1-4), 227-238. doi:10.1007/s10661-010-15082.

J. Sus. Agric. Sci. 44, No. 2 (2018)
Tiwari, B., Chakraborty, S., Srivastava, A. K. and Mishra, A. K. (2017) Biodegradation and rapid removal of methyl parathion by the paddy field cyanobacterium Fischerella sp. Algal. Research, 25, 285-296

Trivedi, V. D., Bharadwaj, A., Varunjikar, M. S., Singha, A. K., Upadhyay, P., Gautam, K., and Phale, P. S. (2017) Insights into metabolism and sodium chloride adaptability of carbaryl degrading halotolerant Pseudomonas sp. strain C7. Archives of Microbiology, 199 (6), 907-916.

Van Dyk, J. S., and Pletschke, B. (2011) Review on the use of enzymes for the detection of organochlorine, organophosphate and carbamate pesticides in the environment. Chemosphere, 82 (3), 291-307. doi:10.1016/j.chemosphere.2010.10.033.

Velázquez-Fernández, J. B., Martínez-Rizo, A. B., Ramírez-Sandoval, M. and Domínguez-Ojeda, D. (2012) Biodegradation and bioremediation of organic pesticides, Pesticides-Recent Trends in Pesticide Residue Assay: InTech.

Vogt, C., and Richnow, H. H. (2014) Bioremediation via in situ microbial degradation of organic pollutants. Adv Biochem. Eng. Biotechnol. 142, 123-146. doi:10.1007/10_2013_266.

Wang, J., Zhu, L., Wang, Q., Wang, J., and Xie, H. (2014) Isolation and characterization of atrazine mineralizing Bacillus subtilis strain HB-6. PLOS One, 9 (9), e107270. doi:10.1371/journal. pone. 0107270 .

Wang, W., and Wu, Y. (2017) Combination of zerovalent iron and anaerobic microorganisms immobilized in luffa sponge for degrading 1,1,1-trichloroethane and the relevant microbial community analysis. Appl. Microbiol. Biotechnol. 101(2), 783-796. doi:10.1007/s00253-016-7933-6

Wang, X., Liu, L., Yao, M., Zhang, H., and Bao, J. (2017) Degradation of Carbofuran in Contaminated Soil by Immobilized Laccase. Polish Journal of Environmental Studies, 26 (3), 1305-1312.

WHO. (2010) The WHO recommended classification of pesticides by hazard and guidelines to classification 2009.

Wohlfahrt-Veje, C., Main, K. M., Schmidt, I. M., Boas, M., Jensen, T. K., Grandjean, P., . . Andersen, H. R. (2011) Lower birth weight and increased body fat at school age in children prenatally exposed to modern pesticides: a prospective study. Environ. Health, 10, 79. doi:10.1186/1476-069X-10-79. 
Wong, C. S. (2006) Environmental fate processes and biochemical transformations of chiral emerging organic pollutants. Anal. Bioanal. Chem. 386 (3), 544-558. doi:10.1007/s00216-006-0424-3.

Xiao, P., Mori, T., Kamei, I., Kiyota, H., Takagi, K., and Kondo, R. (2011) Novel metabolic pathways of organochlorine pesticides dieldrin and aldrin by the white rot fungi of the genus Phlebia. Chemosphere, 85 (2), 218-224. doi:10.1016/j.chemosphere.2011.06.028.

Yan, Q. X., Wang, Y. X., Li, S. P., Li, W. J. and Hong, Q. (2010) Sphingobium qiguonii sp. nov., a carbaryl-degrading bacterium isolated from a wastewater treatment system. Int. J. Syst. Evol. Microbiol. 60 (Pt 12), 2724-2728. doi:10.1099/ijs.0.020362-0.

Ye, C. (2003) Environmental behavior of the herbicide acetochlor in soil. Bull. Environ. Contam. Toxicol. 71 (5), 919-923. doi:10.1007/s00128-001-0217-8.

Yuan, F., Hu, C., Hu, X., Qu, J., and Yang, M. (2009) Degradation of selected pharmaceuticals in aqueous solution with UV and UV/H(2)O(2). Water Res. 43 (6), 1766-1774. doi:10.1016/j.watres.2009.01.008.

Zhang, B., Pan, X., Cobb, G. P., and Anderson, T. A. (2009) Uptake, bioaccumulation, and biodegradation of hexahydro-1,3,5-trinitro-1,3,5-triazine (RDX) and its reduced metabolites (MNX and TNX) by the earthworm (Eisenia fetida). Chemosphere, 76 (1), 76-82. doi:10.1016/j.chemosphere.2009.02.021.

Zhang, H., Zhang, Y., Hou, Z., Wang, X., Wang, J., Lu, Z., . . . Pan, H. (2016) Biodegradation potential of deltamethrin by the Bacillus cereus strain $\mathrm{Y} 1$ in both culture and contaminated soil. International Biodeterioration \& Biodegradation, 106, 53-59.

Zhang, R., Xu, X., Chen, W., and Huang, Q. (2016) Genetically engineered Pseudomonas putida X3 strain and its potential ability to bioremediate soil microcosms contaminated with methyl parathion and cadmium. Appl. Microbiol. Biotechnol. 100(4), 1987-1997. doi:10.1007/s00253-015-7099-7.

Zhang, Y., Zhu, L., Wang, J., Wang, J., Su, B., Zhang, C., . . . Li, C. (2016) Biodegradation of Endosulfan by Bacterial Strain Alcaligenes faecalis JBW4 in Argi-Udic Ferrosols and Hapli-Udic Isohumosols. Water, Air, \& Soil Pollution, 227 (11), 425.

Zhao, W., Xu, L., Li, D., Li, X., Wang, C., Zheng, M., ... Qiu, L. (2015) Biodegradation of thifensulfuron-methyl by Ochrobactrum sp. in liquid medium and soil. Biotechnol. Lett. 37 (7), 1385-1392. doi:10.1007/s10529-015-1807-3.

Zheng, G., Selvam, A., and Wong, J. W. C. (2012) Oilin-water microemulsions enhance the biodegradation of DDT by Phanerochaete chrysosporium. Bioresource Technology, 126, 397-403. doi:https://doi. org/10.1016/j.biortech.2012.02.141.

Zhou, J. H., Sun, X. W., Hu, F., and Li, H. X. (2013) [Isolation, screening and identification of prometryne-degrading bacteria and their degrading characteristics]. Huan Jing Ke Xue, 34 (7), 28942898.

(Received:7/4/2018; accepted:30/6/2018) 